\title{
INFLUÊNCIA DA CULTURA LÁTICA NAS CARACTERISTICAS FÍSICAS E ORGANOLÉPTICAS DO IOGURTE
}

\author{
EDISON NEIROTTI ROUMAS
}

Orientador: ANTONIO JOAQUIM DE OLIVEIRA

Dissertação apresentada à Escola Superior de Agricultura "Luiz de Queiroz", da Universidade de São Paulo, para obtenção do título de Mestre em Agronomia. Área de Concentração: Microbiologia Agrícola.

$P \mid R A C I C A B A$

Estado de São Paulo - Brasil

Setembro, 1984 
ii.

A meus pais

Edison e Cleria

Ao meu irmão

Enrique

A minha companheira

Maria Aparecida

DEDICO 


\section{AGRADECIMENTOS}

Ao Prof. Dr. Antonio Joaquim de Oliveira, pela orientação, dedicação e amizade brindadas nestes dois anos de trabalho.

Aos Prof. Dr. João Gustavo Brasil Caruso e Prof.Dr. Rodolpho de Camargo pelas valiosas sugestões apresentadas e constante incentivo de ami gos.

A Bel. Rosana Cristina Pereira Parente e ao Prof. Dr. Issao Shirose, pelo valioso assessoramento nas anälises estatísticas.

A Srta. Rosa Maria Alves, pelo apoio e amizade demonstrados, e pelo seu valioso trabalho datilogrä́fico e correção do Português deste tra balho.

Aos Professores do Curso de Mestrado em Microbiologia Agrícola pelos en sinamentos e pela contribuição à minha formação profissional.

Aos Professores e Funcionários do Departamento de Tecnologia Rural da ESALQ/USP pela sua voluntāria e ativa participação no painel de de gustadores e outros incalculáveis serviços prestados.

$\bar{A}$ Organização dos Estados Americanos (OEA), pelo auxỉlio financeiro concedido, ao Departamento de Tecnologia Rural da ESALQ/USP pelos recursos oferecidos e à Faculdade de Humanidades e Ciencias de Montevidéu, Uruguai, pela oportunidade oferecida para realizar este cur so.

A todos os que de alguma forma colaboraram para a realização deste trạ balho. 
RESUMO $\ldots \ldots \ldots \ldots \ldots \ldots \ldots \ldots \ldots \ldots \ldots \ldots \ldots \ldots \ldots \ldots \ldots \ldots \ldots \ldots \ldots$

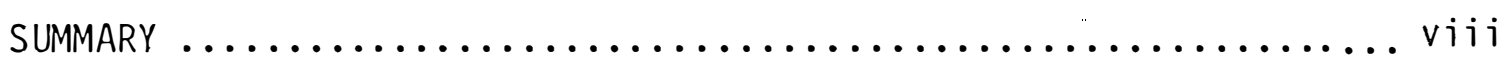

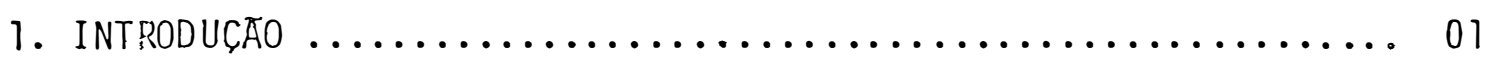

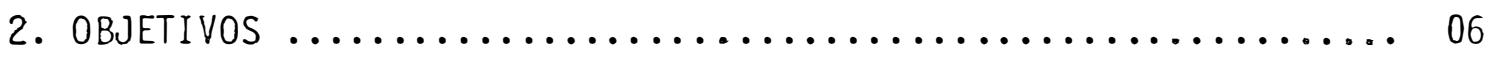

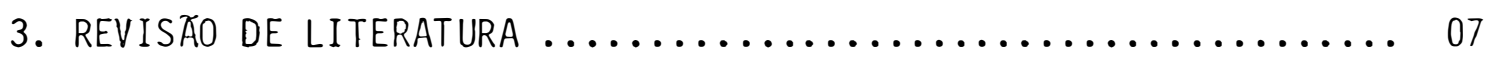

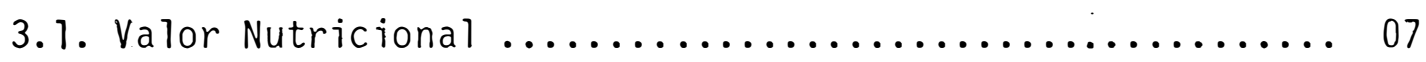

3.2. Propriedades Profiláticas e Terapêuticas .............. 11

3.3. Comportamento das Culturas Láticas ................ 17

3.3.1. Protocoperação $\ldots \ldots \ldots \ldots \ldots \ldots \ldots \ldots \ldots \ldots \ldots \ldots$

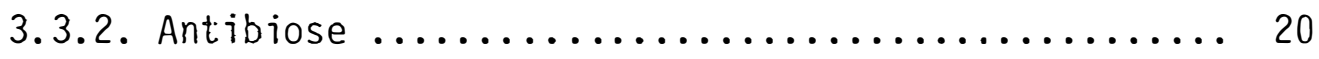

3.4. Efeitos das Culturas Láticas na Fermentação do Leite e sua Influência na Qualidade do Iogurte ........... 27

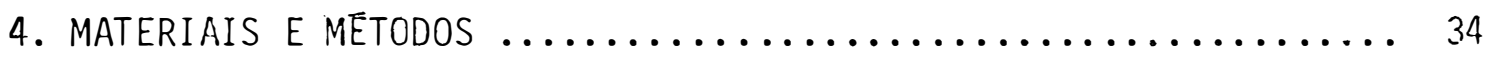

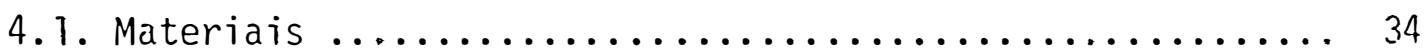

4.1.1. Culturas Läticas ....................... 34

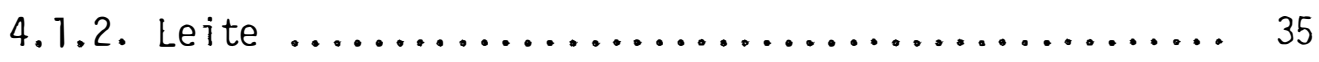

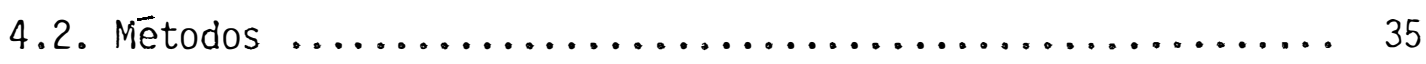

4.2.1. Combinações de Culturas ................. 35

4.2.2. Condições dos Experimentos ............... 36

4.2.3. Preparo do Iogurte $\ldots \ldots \ldots \ldots \ldots \ldots \ldots \ldots \ldots . . \ldots \ldots$

4.2.4. Anālises Realjzadas....................... 37

4.2.4.7. pH ........................... 37

4.2.4.2. Anātise Sensorial ................ 37 
Pāg.

4.2.4.2.1. Painel de Degustadores ..... 37

4.2.4.2.2. Provas de Degustação ...... 40

4.2.4.3. Anāitise Estatística ............... 43

5. RESULTADOS E DISCUSSAO $\ldots \ldots \ldots \ldots \ldots \ldots \ldots \ldots \ldots \ldots \ldots \ldots$

5.1. Resultados ............................. 44

5.1.1. Aspecto Geral e Cor .................... 44

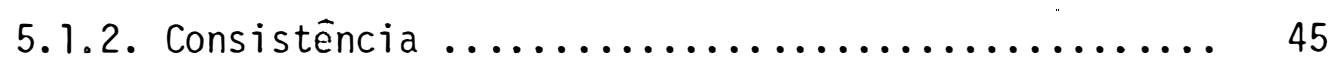

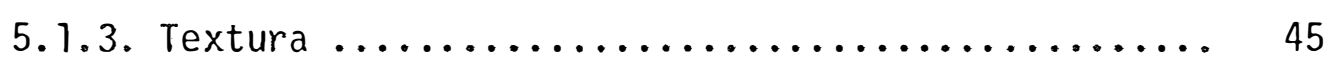

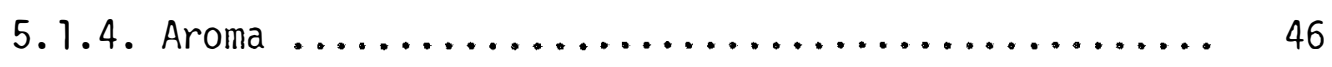

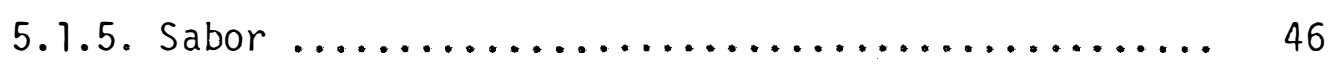

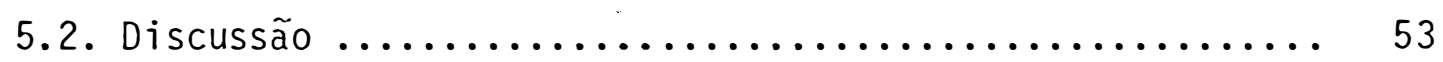

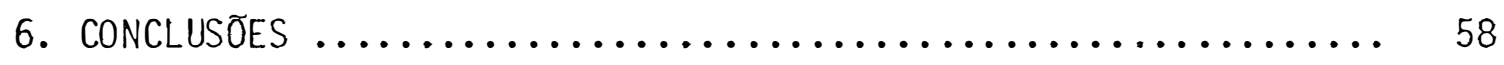

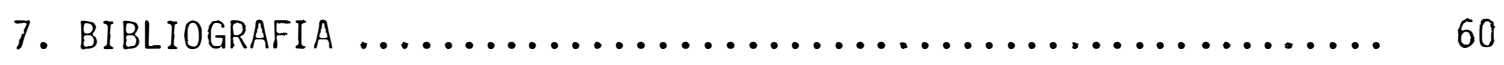




\title{
INFLUENCIA DA CULTURA LATTICA NAS CARACTERISTICAS \\ FISICAS E ORGANOLEPTICAS DO IOGURTE
}

\author{
Autor: $\quad$ EDISON NEIROTTI ROUMAS \\ Orientador: ANTONIO JOAQUIM DE OLIVEIRA
}

\section{RES U M O}

A influência das culturas láticas nas características físicas e organolépticas do iogurte foi estudado através da inoculação do leite com diferentes combinações dessas culturas. Também foram estú dadas as características físicas e organolépticas do produto de cada combinação ao longo de um período de armazenamento de 30 dias, a $4^{\circ} \pm$ $0,5^{\circ} \mathrm{C}$.

Após o tratamento térnico, o leite foi inoculado com $4 \%$ de cultura lática e incubado a $42{ }^{\circ} \mathrm{C}$ durante 4 horas. Para isso, uti lizaram-se 4 tipos de combinações láticas diferentes: iogurte tipo I

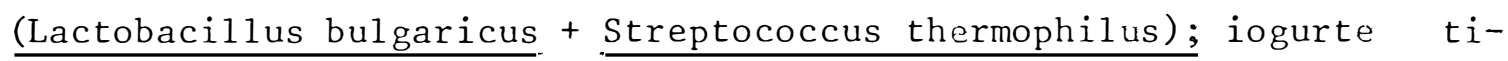
po II (L. bulgaricus $+\underline{S}$. thermophilus + Lactobacillus acidophilus) ; iogurte tipo III (L. bulgaricus $+\underline{S}$. thermophilus $+\underline{\text { Streptococcus lac- }}$ $\underline{\text { tis }}$ var. diacetylactis) e iogurte tipo IV (L. bulgaricus $+\underline{\text { S. }}$ thermophilus + Leuconostoc cremoris). 
vii.

Um painel de degustadores especialmente treinado ava liou a qualidade dos 4 produtos finais com 24 horas, 15 dias e 30 dias de armazenamento. $0 \mathrm{pH}$ do iogurte foi medido imediatamente após a incu bação e refrigeração do produto, assım como em cada uma das provas de degustação.

A anālise estatística dos resultados da anālise sensorial mostrou que o iogurte tipo IV foi o melhor qualificado pelo pai nel de degustadores. 
viii.

\title{
LACTIC CULTURES INFLUENCE ON YOGURT PHYSICAL AND ORGANOLEPTICAL CHARACTERISTICS
}

\author{
Author: EDISON NEIROTTI ROUMAS \\ Adviser: ANTONIO JOAQUIM DE OLIVEIRA
}

\section{S U M M A R Y}

Lactic cultures influence on yogurt physical and orga noleptical characteristics were studied by milk inoculation with diffe rent combinations of these cultures. The physical and organoleptical characteristics of the product from each culture combination were also studied during a 30 days storage at $4^{\circ} \pm 0,5^{\circ} \mathrm{C}$.

Afther thermic treatment, milk was inoculated with $4 \%$ of lactic culture and incubated at $42^{\circ} \mathrm{C}$ for 4 hours. Four different cul ture combinations were used: yogurt type I (Lactobacillus bulgaricus. + Streptococcus thermophilus); yogurt type II (L. bulgaricus + $\underline{\text { S. thermo- }}$ $\underline{\text { philus }}+\underline{\text { Lactobacillus acidophilus); yogurt type III (L. bulgaricus }}+$ S. thermophilus + Streptococcus lactis var. diacetylactis) and yogurt type IV (L. bulgaricus $+\underline{S}$. Thermophilus + Leuconostoc cremoris). 
A taste panel evaluated the four final products quaIity at 24 hours, 15 days and 30 days of storage. The yogurts pH were measured after incubation and refrigeration of the product and in every one the tasting tests.

The statistical analysis of the tasting tests results showed that yogurt type IV was the best qualified by the panelists. 


\section{INTRODUÇĀO}

A fermentação é um dos métodos clässicos de preserva ção de alimentos. No decorrer dos anos este método foi evoluindo trans formando-se em uma arte sofisticada. O leite pode ser fermentado por bactérias, leveduras e fungos, para produzir uma variedade de produtos tais como iogurte, queijo, manteiga, etc.

As modificações do leite por microorganismos afetam as propriedades físico-químicas e o valor econômico do leite. As mudanças físico-químicas afetam as propriedades tais como sabor, consistência e valor nutritivo. O valor econômico do leite $\vec{e}$ melhorado pelo prolongamento do tempo de vida dos produtos lácteos derivados, pelo fato dos mesmos poderem ser armazenados (KILARA e SHAHANI, 1978). A importância do iogurte no mercado nacional vem se incrementando de forma considerá vel nos últimos anos, como revelam as estatísticas brasileiras de produ 
ção de leite cru e. leites fermentados (tabela 1). Nesta pode-se ver a importāncia destes ültimos, pois enquanto a produção de leite não conseguiu se duplicar, a produção de leite fermentado e iogurte aumentou um pouco mais de 266 vezes. Se o iogurte é importante derivado do leite no mercado brasileiro, em outros países, mais desenvolvidos, onde os investimentos em tecnologia e propaganda são maiores (tabela 2) ele alcança maiores indices de produção e consumo.

o iogurte, assim como muitos dos derivados do leite, nada mais é do que o resultado de tentativas iniciais de se preservar - leite, uma vez que a adição de preservativos químicos aos produtos de laticínios não è permitida.

Os produtos derivados do leite podem ser conservados de duas formas:

a) por desidratação, ou seja, remoção de diferentes porções de água do leite integral, como no caso dos produtos con densados e desidratados;

b) pelo desenvolvimento de preservativos, como no caso dos leites fermentados, iogurte e queijo, os quais são preservados, parcialmente, pelo ácido lático produzido pela atividade bacteriana (MARTINELLI FILHO, s.d.). 
TABELA 1 - Produção brasileira de leite crū, leite fermentado e Iogurte.

\begin{tabular}{|c|c|c|}
\hline ANO & $\begin{array}{l}\text { Produção de leite } \\
\qquad \operatorname{cr} \overline{\mathbf{u}}(1.000 \mathrm{~L})\end{array}$ & $\begin{array}{c}\text { Produção de leite fermen } \\
\text { tado e iogurte (ton.) }\end{array}$ \\
\hline 1967 & 6.818 .107 & 369 \\
\hline 1968 & 6.909 .350 & 477 \\
\hline 1969 & 6.993 .048 & 495 \\
\hline 1970 & 7.125 .242 & 1.236 \\
\hline 1971 & 7.109 .430 & 7.589 \\
\hline 1972 & 7.141 .607 & 17.314 \\
\hline 1973 & 7.248 .828 & 30.707 \\
\hline 1974 & 7.381 .984 & 45.849 \\
\hline 1975 & 8.116 .105 & 67.367 \\
\hline 1976 & 8.566 .646 & 67.773 \\
\hline 1977 & 8.565 .637 & 69.041 \\
\hline 1978 & 9.782 .169 & 73.659 \\
\hline 1979 & 10.187 .226 & 82.978 \\
\hline 1980 & 11.162 .245 & 98.283 \\
\hline
\end{tabular}

FONTE: Boletim do Leite, anos 1971 (No 513), 1972 (No 525), 1975 (No $556)$. 
TABELA 2 - Estimativa para 1968-72 do consumo de iogurte "per capita"/ ano em nümero de potes de $120 \mathrm{ml}$.

\begin{tabular}{lr}
\hline Holanda & 110,1 \\
França & 46,1 \\
Alemanha & 20,7 \\
Inglaterra & 4,0 \\
Chile & 2,0 \\
E.U.A. & 1,2 \\
Canadá & 1,0 \\
Brasil & 0,7 \\
\hline
\end{tabular}

FONTE: Boletim do Leite, 1973 (Nọ 539).

o iogurte foi desenvolvido, empiricamente, há vários séculos, a partir do leite naturalmente contaminado, o qual se acidifi cou a temperaturas altas, provavelmente entre $40-50^{\circ} \mathrm{C}$. Com o passar do tempo a produção do iogurte se transformou em um processo sofisticado e controlado, conseguido por meio do uso de certas culturas láticas.

As propriedades de um bom iogurte são medidas por seu sabor e aroma balanceados; acidez média, adequada para produzir um sa bor nem ácido, nem doce; corpo de consistência viscosa; textura suave, lisa, sem presença de bolhas de gás; e, aspecto normal (DAVIS, 1975). 
Porëm, as propriedades mais importantes do iogurte são as nutricionais, profiláticas e terapêuticas que the são atribuídas. 
6.

\section{OBJETIVOS}

0 presente trabalho tem por objetivo determinar a in fluência de certas combinações de culturas läticas nas características organolépticas do iogurte, incluindo:

a) estudo e comparação de cada uma dessas combinações de culturas com o fim de determinar as características e a qualidade de seus respectivos produtos finais;

b) determinar o grau de aceitação popular para cada uma des sas combinações;

c) estudo das características físicas e organolépticas do produto de cada combinação ao longo do período de arnaze namento. 


\section{REVISÃO DE LITERATURA}

\subsection{Valor Nutricional}

o alto valor nutricional dos alimentos fermentados es tá relacionado com a síntese de enzimas, vitaminas e outros fatores que melhoram o aspecto nutricional do produto (AYEBO e SHAHANI, 1980). As sim, num experimento feito com um grupo de pessoas entre 15 e 17 anos de idade, alimentadas com leite fermentado por lactobacilos, HAMADA et alii (1971) observaram que este grupo experimental, comparado com um grupo controle, teve um incremento adicional em peso corporal e não so freu infecção intestinal por desinteria.

DAVIS (1975) diz que o iogurte é um produto de considerável valor nutritivo, maior do que o do leite em seu estado natural, dado seu alto conteūdo de proteinas, vitaminas, cálcio, fosfato e potássio. Assim, por exemplo, os microrganismos envolvidos na produção 
do iogurte, ao crescerem no leite, produzem algumas das vitaminas do complexo B, conferindo ao mesmo um valor nutricional extra, em benefí cio do consumidor.

Porém, o conteūdo de vitaminas no iogurte e no leite tem sido um tema polêmico na literatura, e, ainda não bem esclarecido. Alguns autores consideram o iogurte como uma fonte de vitaminas mais rica que o leite, enquanto outros têm demonstrado que o teor de vitami nas do leite decresce durante a produção do iogurte. O teor de vitami nas no iogurte é influenciado por fatores tais como o tratamento térmi co a que foi submetido o leite, pelo sistema de concentração desse lei te (RO ou UF) e pelas culturas láticas usadas (DEETH e TAMIME, 1981).

DAVIS (1978) diz que o iogurte é "uma indústria prodụ tora de vitamina $B^{\prime \prime}$. SHAHANI e CHANDAN (1979) estudaram o conteúdo de vitaminas do complexo $B$ em leite e seus derivados fermentados; no caso do iogurte, ele continha maior quantidade de ácido fólico, biotina,nia cina e vitamina B12 que o leite do qual provinha. MITIC et alii (1974) encontraram 3 linhagens de Lactobacillus bulgaricus que sintetizam vi tamina B12 e SHAHANI et alii (1974) afirmam que as culturas láticas u sadas para a produção do iogurte e do queijo Cottage produzem ácido fó lico e vitamina B12. Ao contrário deles, ACOTT e LABRIZA (1972) demons traram que com exceção do ácido nicotinico, o iogurte continha uma quan tidade de vitaminas menor que o leite. Vitamina Al, B12, C, colina e biotina eram, respectivamente, $56 \%, 72 \%, 71 \%, 75 \%$ e $61 \%$ menores no io-gurte que no leite do qual este tinha sido feito. 
As culturas läticas "starters" consomem algumas vitaminas e sintetizam outras em diferentes quantidades durante o processo de fermentação do iogurte. Isto depende da linhagem bacteriana,da quan tidadedo inóculo usado e das condições de fermentação (SHAHANI et alii 1974). REDDY et alii (1976) encontraram que o niacin e o ácido fólico aumentaram durante a produção do iogurte, enquanto que a vitamina B12, biotina e ácido pantotênico decresceram.

SHANKAR E LAXMINARAYANA (1974) demonstraram um incre mento do ácido fólico e um decréscimo de tiamina e riboflavina. CERNA (1973) e KARLIN (1961) postularam que a perda de vitamina B12 pode ser reduzida com a adição de Propionibacterium freudenreichii subsp. shermanii à cultura do iogurte. RASIC e PANIC (1963) também assinalaram a redução do teor de vitamina $B 12$.

CZARNOCKA-ROCZNIAKOWA e WOJEWODZKA (1970) demonstraram que a vitamina C não é utilizada pelas bactérias láticas durante a produção do iogurte.

SHIMHAEE e KESHAVAREZ (1974) afirmam que os produtos lācteos fermentados são, em quantidade de calorias, similares ao leite, mas são mais nutritivos e mais facilmente digeríveis.

RASIC et alii (1971) além de demonstrarem que o valor biológico das proteinas do iogurte $(87,3 \%)$ é maior que o das proteinas do leite $(81,4 \%)$, demonstraram também que os índices de digestibilidade total dos aminoácidos do iogurte $(24,21 \%)$ é maior que os de digestí bilidade dos aminoácidos do leite (23,01\%). Também DOAN e DIZIKES (1942) compararam a digestibilidade do leite e do iogurte; na primeira hora é digerido $32 \%$ do primeiro e $91 \%$ do segundo e, em 3 horas, é digerido $44 \%$ 
10.

do leite e $95,5 \%$ do iogurte. Isto deve-se ao fato de que as proteinas, carboidratos e gorduras do leite foram pré-digeridas pelas culturas do iogurte, facilitando assim a ação das enzimas digestivas (BRESLAW e KLEYN, 1973).

Essa proteolise que, por ação das bactérias 1áticas so fre a caseina, faz com que o iogurte possa ser usado, sem problemas, inclusive por aquelas pessoas que não podem digerir as proteinas do leite (DAVIS, 1975).

Segundo RENNER (1982) as proteinas de.origem animal são de valor biológico superior ao das proteinas de origem vegetal, de vido ao alto teor de aminoácidos essenciais. Segundo RASIC e KURMANN (1978) as proteinas do leite, comparadas a outras fontes proteicas, são ricas em aminoācidos essenciais tais como triptofano, leucina, isoleucina, treonina, valina, fenilalanina e lisina. Entre as proteinas de 으 rigem animal, as do leite classificam-se em segundo lugar, depois da proteina do ovo integral. Porēm, as proteinas do leite, livres de ācidos nucleicos, são de melhor valor dietético que as da carne. Estas ū1 timas são, biológicamente, de grande valor alimentício mas, quimicamen te, devido à presença de ácidos nucleicos (purinas), conduzem à forma ção de ácido úrico em proporção acima do normal. o ácido úrico causa a uremia e a formação de cālculos na bexiga (BALENSIFER, 1971).

Além disso, as proteinas do leite se distinguem das demais por serem ricas em fósforo. As fosfoproteinas somente são encon tradas na natureza, em maiores concentrações nos organismos em cresci- 
11.

mento, concluindo-se que, possivelmente, caberia a elas cumprir funções específicas durante a fase do crescimento, como por exemplo, na formação dos ossos (MANSON, 1975).

Também para as pessoas mais idosas o leite e seus derivados são importantes fontes proteicas, uma vez que com o avanço da idade, a taxa de conversão das proteinas se vê reduzida, manifestando-se assim, uma maior necessidade de aminoácidos essenciais e, portanto, de proteinas (DAVIES e HOLDSWORTH, 1978). O consumo de proteina de al to valor nutritivo transforma-se a partir do 509 ano de idade em um fa tor preventivo das moléstias relacionadas com a idade, particularmente molēsticas hepáticas (KETZ, 1972). Além do valor nutritivo dado pela proteina do leite, no iogurte, aproximadamente $1 \%$ da sua matéria seca é constituída por proteina bacteriana (BLANC, 1973). ERDAAN et alii (1977) e SHANKAR e LAXMINARAYANA (1974) sugerem que a proteina bacteria na, contida no iogurte, pode ser uma fonte muito rica de aminoácidos es senciais.

\subsection{PROPRIEDADES PROFILATICAS E TERAPÊUTICAS}

Alëm de seu alto valor nutricional, o iogurte tem im portantes propriedades profiláticas e terapêuticas. FERREIRA (1979) cí ta que o valor terapéutico do iogurte e do leite acidófilo está associado aos microrganismos envolvidos no processo de fermentação e aos 
metabolitos por eles produzidos. Assim, KROGER (1978) assinala que o iogurte è um importante substituto para aquelas pessoas que não podem ingerir o leite por não tolerarem a lactose. O mesmo autor ressalta que 9 dentre 20 pessoas que sofrem de osteoporoses (fragilidade óssea), de vido a uma intolerância à lactose, deixaram de tomar leite nos ūltimos 5 anos, o que reduziu a ingestão de cálcio, provocando a referida doen ça. Isto poderia ser evitado, se o consumo do leite fosse feito na for ma de um seu derivado: iogurte.

DUPUIS (1964) demonstrou que a eficiência de absorção e retenção de cálcio em ratos alimentados com iogurte foi maior que em ratos alimentados com dietas normais balanceadas, contendo cálcio em outras formas.

KELLY (1984) explica que a intolerância à lactose é $\underline{u}$ ma condição na qual, o açücar do leite não é hidrolizado em seus dois monossacarideos componentes, a glicose e a galactose. A enzima lactase é a responsāvel pela catalização dessa reação e nos indivíduos intolerantes à lactose a enzina é deficiente e assim, o açūcar do leite passa através do intestino sem sofrer transformação alguma. Desta forma provoca diarréia, pois, rompe o equilíbrio osmötico existente no intes tino e a água penetra no mesmo; parte dessa lactose é fermentada pela flora bacteriana natural do intestino formando gás (H) com a consequen te compressão e inchamento do ventre. Alēm disso, a intolerância à lactose produz eczema, cōlica, garupa, constipação (prisão de ven- 
tre), dor de cabeça, asma, etc. No iogurte parte dessa lactose jā foi hidrolizada pelas bactérias läticas e segundo alguns autores, essa di minuição varia de 20\% (SPECK, 1983), 34,6\% (GOODENOUGH e KLEYN, 1975) até 50\% (DEETH e TAMIME, 1981).

KOLARS et alii. (1984), em uma pesquisa recente, concluiram que a atividade da lactase de origem bacteriana substitui a perda da lactase endógena e produz uma melhor absorção da lactose inge rida no iogurte.

GOODENOUGH e KLEYN (1976) demonstraram que ratos alimentados com iogurte com culturas vivas foram capazes de digerir a lac tose mais eficientemente que aqueles alimentados com iogurte pasteurizado. Isto coincide com o afirmado por SPECK (1977) quando diz que as pessoas são capazes de digerir a lactose mais eficientemente devido à lactase bacteriana de iogurtes não pasteurizados. Estes fatos podem ser explicados pois a morte e lise dessas células bacterianas no intestino libera a lactase a qual pode ser utilizada pelo indivíduo para hidrolí zar a lactose contida no iogurte consumido (KILARA e SHAHANI, 1976).

Pessoas que sofrem de problemas gastrointestinais in duzidos por uma mudança ou alteração da flora microbiana, ou por intoxicações alimentares, podem reajustar esses distūrbios reintroduzindo uma flora microbiana benigna como a do iogurte, que inibe o crescimento dos patógenos ou leveduras (KROGER, 1978).

o Tratamento oral extensivo com antibióticos pode que brar o equilibrio existente na microflora intestinal, podendo ocorrer assim uma diminuição no nümero de lactobacilos e um crescimento de or 
ganismos normalmente presentes em menor proporção, tais como, estafilo cocos, enterobactérias, bactérias anaeróbicas formadoras de esporos, pseudomonas e leveduras, muitos dos quais podem ser patógenos em poten cial e provocar uma série de desordens (FERREIRA, 1979). DAVIS (1952a) descreveu um caso em que o iogurte foi usado para restabelecer a flora normal no intestino de pacientes que haviam sido tratados com penicili na.

MAYNON-WHITE e IRVING (1951) e DAVIS (1952b) descreve ram o uso do iogurte no tratamento de cianose infantil, doença que re sulta da redução de nitratos da água a nitritos na parte superior do trato intestinal por microrganismos tais como Escherichia coli. Estes nitritos passam para o sangue e, a hemoglobina se converte em meta-he moglobina assumindo coloração azulada. Os adultos aparentemente não so frem desta doença, devido a uma maior acidez no intestino delgado ( $\mathrm{pH}$ menor que 4) o que inibe o crescimento destas bactérias redutoras de nitrato (FERREIRA, 1979). MAYNON-WHITE e IRVING (1951) sugeriram que o tratamento dos pacientes com iogurte deveria acabar com esses problemas, por causa da repressão à Escherichia coli no intestino.

0 iogurte tem sido usado em problemas gastrointestí nais tais como a diarréia, particularmente a diarréia infantil (NIV et alii, 1963), gastroenterite (DAVIS e LATTO, 1957), constipação (FER RER e BOYD, 1955). HALDEN (1964) cita o uso do iogurte para a regenera ção da flora intestinal, depois de sua destruição pelo uso de antibiōticos. 
Tem surgido considerāvel controvērsia quanto à eficiência do iogurte como agente terapêutico. O tema central desse debate é sobre a possibilidade dos microrganismos do iogurte sobreviverem nas condições gāstricas (acidez do estômago) e intestinais (teor de sal de bile do duodeno) e se são capazes de se implantarem no intestino. ROCHIETTA (1975), SALVADORI e SALVADORI (1974) e GOODE NOUGH e KLEYN (1976) têm encontrado nümeros significantes de microrga nismos do iogurte que podem sobreviver à passagem através do trato in testinal.

HARGROVE e ALFORD (1978) informaram que em ratos ali mentados com iogurte, o Lactobacillus bulgaricus foi frequentemente en contrado na parte final do intestino, enquanto que Streptococcus termophilus não.

SPECK (1977) tem demonstrado que os microrganismos do

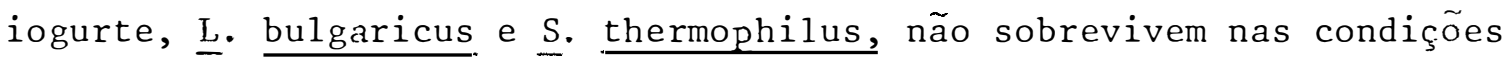
ácidas do estômago e de sal da bile do intestino. Portanto, os benefí cios do iogurte derivam do conteúdo das culturas (enzimas e metabolitos) mais que da viabilidade das mesmas no intestino.

Atualmente acredita-se que $\underline{L}$. bulgaricus não pode se instalar no intestino, enquanto que L. acidophilus sim. Este ültimo é um habitante comum do intestino, boca e vagina, enquanto que $\underline{L}$. bulgaricus não o é (SANDINE, 1979). Portanto, é improvável que L. bulgaricus possa inibir a putrefação intestinal e seja efetivo no tratamento de desordens intestinais (MITSUOKA, 1972). O iogurte também tem sido u sado em indivíduos com alergia à proteina do leite, jā que as protei- 
nas do iogurte têm uma ação alergênica menor (NIV et alii, 1963; DAVIS, 1975 a e b).

Uma suplementação da dieta normal, com derivados fer mentados do leite, em humanos e animais de laboratório, demonstrou uma tendência a diminuir o nível de colesterol no soro sanguíneo (AYEBO e SHAHANI, 1980).

MANN e SPOERRY (1974) realizaram um estudo relacionan do uma dieta com leite fermentado e o nível de colesterol, em 24 guer reiros da tribo Massai na África, cuja idade variava de 16 a 23 anos. Depois de 3 semanas de dieta, houve, em todos eles, um aumento de peso entre 2,3 e $2,7 \mathrm{~kg}$ e uma diminuição do nível de colesterol no soro san guíneo de 8,19 atē $28 \mathrm{mg} / 100 \mathrm{ml}$. Estes autores concluiram que o leite fermentado ingerido tinha introduzido algum fator que impede a síntese de colesterol.

REDDY et alii (1973) informaram que em ratos machos com células tumorais asciticas de Erlich, após 8 dias sendo alimentados com ração e iogurte apresentaram $28 \%$ de inibição na proliferação dessas células tumorais, com relação a ratos alimentados somente com raçao.

Os lactobacilos do iogurte são os responsáveis pela produção de substâncias que reduzem a proliferação de certos tumores, pelo controle de um equilíbrio da flora bacteriana intestinal e da pro dução por parte desta de compostos químicos carcinogênicos (SHAHANI e AYEBO, 1980). 
E importante a permanência das culturas do iogurte viāa veis durante o armazenamento do mesmo. Porém os produtores começaram a pasteurizar seu iogurte com o fim de destruir as culturas. KELLY (1984) diz que isto visa: 1) a centralização da produção, com possibilidades de transportar a maiores distância; 2) uma vida de prateleira mais longa; 3) a flutuação da temperatura durante a distribuição permite às células viāveis continuarem o seu crescimento e produção de ácido (SIECK, 1977). Porém, vários autores sugerem que o iogurte não deve so frer esse tratamento térmico pelos seguintes motivos: 1) Devido ao fa to de que e desnecessário, já que segundo DAVIS (1971) a sua vida de prateleira e de uns 10 dias a uma temperatura que não exceda os $5^{\circ} \mathrm{C}$ e, segundo KURMANN (1977) é de 2 a 4 semanas; 2) o tratamento com calor diminui o conteúdo de vitaminas; 3) o calor destrói a lactase (KRoger, 1978); 4) inativa o efeito antitumoral do iogurte (SHAHANI e CHANDAN, 1979); 5) foi comprovado que diminui a influência que esse produto tem no crescimento dos ratos (HARGROVE e ALFORD, 1980); 6) Elimina o valor do iogurte como fonte de uma florabacteriana benigna que pode ter beneficios em problemas gastrointestinais.

\subsection{Comportamento das Culturas Läticas}

$\bar{E}$ evidente a importância industrial que tem o comportamento das culturas láticas, já que dele depende o sucesso ou o fracasso de um determinado processo.

Combinações de microrganismos mostram diferentes in 
teraçoes quando crescem no leite. Os efeitos variam desde estimulações (protocoperação) até inibição (antibiose). Não se pode predizer a in teração entre microrganismos a partir do crescimento e comportamento que cada um deles apresenta de forma isolada.

Do ponto de vista da produção e conservação dos produ tos 1ácteos, tanto a protocoperação como a antibiose podem ser benéfi cas ou prejudiciais, dependendo do caso de que se trata e dos microrganismos envolvidos.

\subsubsection{Protocoperação}

MARSHALL (1905) e MARSHALL e FERRAND (1908), demonstraram a importância das associações bacterianas na acidificação do leite, encontrando que muitas das bactérias que crescem no leite estimularam o crescimento e a atividade fermentadora das bactērias láticas, sendo que esses efeitos diferem para cada caso em particular. Também ci tam diversos autores que encontraram culturas 1áticas (starters) as quais eram estimuladas em sua produção de àcido por microrganismos

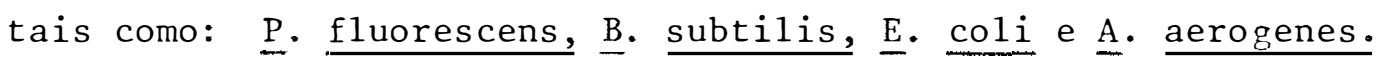
NURMIKKO (1953) demonstrou que diferentes linhagens de bactérias látiças podem crescer juntas em um meio sintētico incapaz de suportar o crescimento de cada uma delas em separado. Ele conclui que cada linhagem produz os fatores de crescimento requeridas pela ou tra. 
o iogurte è o resultado da fermentação do leite por dois tipos de bactérias láticas, Streptococcus thermophilus e Lactobacillus bulgaricus. Estas tēm uma interação mutuamente favorável, mas que nao é obrigatōria (GALESLOOT et alii, 1968; PETTE e LOLKEMA, 1950 e VERINGA et alii, 1968). Tal relação é chamada de protocoperação (ODUM, 1971).

Em cultura mista destas bactérias, essa protocopera çao manifesta-se na produção de uma quantidade de ácido lático maior que a soma das produções de ambas as culturas em separado (PETTE e LOL KEMA, 1950) .

A protocoperação entre as duas bactérias do iogurte se dá através do estímulo ao crescimento do $\underline{S}$. thermophilus pelos amiroācidos e peptidos liberados das proteinas pelo $\underline{L}$. bulgaricus. (MILLER e KANDLER, 1964; PETTE e LOLKEMA, 1950 e SHANKAR e DAVIES, 1977). O cres cimento e produção de ácido do L. bulgaricus é estimulado pela produção de àcido formico, em condições de ausenncia ou baixa concentração de $\mathrm{O}_{2}$, pelo $\underline{\mathrm{s}}$. thermophilus. (AUCLAIR e PORTMAN, 1959). Em alta concentração de $\mathrm{O}_{2}$, estes estreptococos fracassam na produção de ácido förmico. DRIESSEN et alii (1982) demonstraram que o ácido formico não é o único substrato limitante para o crescimento de $\underline{\text { L. bulga- }}$ ricus, e relataram que ele cresce mais rapida e vigorosamente quando o leite contém $31 \mathrm{mg}$ de $\mathrm{CO}_{2} / \mathrm{kg}$, e is to acontece quando o leite é inocula do com uma cultura mista de ambas as bactérias. Essa quantidade de $\mathrm{CO}_{2}$ é produzida pelo $\underline{S}$. thermophilus mais rapidamente em cultura mista que em cultura pura, devido ao estímulo favorável que o $\underline{\text { L. bulgaricus }}$ pro duz sobre aquele microrganismo; assim, $\mathrm{O}_{2} \mathrm{CO}_{2}$ rapidamente està em ex 


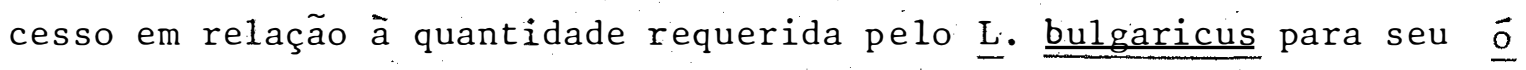
timo crescimento.

\subsubsection{Antibiose}

SPECK (1972) diz que uma grande quantidade dos alimen tos hoje elaborados, depende, em parte, da atividade de certos micror ganismos para sua preservação. Já que. certas linhagens de microrganis mos e culturas "starters" possuem atividade inibitória sobre microrga nısmos patógenos dos alimentos, elas devem receber atenção preferencial no seu uso na produção desses alimentos. Se os "starters" podem prevenir o crescimento de patógenos nos alimentos, isso proveria uma qualidade adicional aos alimentos fermentados. Este fato oferece uma perspectiva promissora ao controle biológico desses patógenos sem ter que recorrer a tratamentos físicos mais rigorosos dos alimentos, ou à adição de mais preservativos químicos.

Assim, MATHER e BABEL (1959) jā tinham observado, em creme para queijo Cottage, que $\underline{L}$. cremoris inibia a atividade de: $\underline{\text { P. }}$

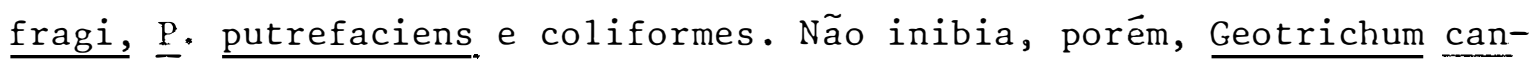

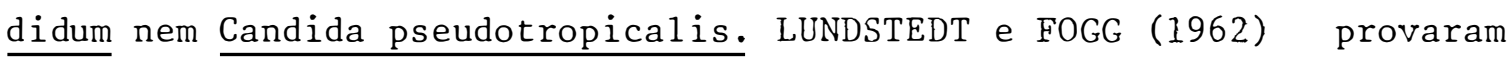
que a adição de $\underline{S}$. diacetylactis ao creme do queijo cottage incrementou o sabor e aroma e prolongou a vida de prateleira.

MARTH e HUSSONG (1963) estudaram, no leite, a inibição de 15 espécies bacterianas diferentes por $\underline{L}$. cremoris e determinaram que essa inibição foi de $89,1 \%$ a pH 4,5 e de $63,3 \%$ a pH 5,1. Os micror 
ganismos mais sensíveis foram: $\underline{\text { S }}$ aureus, P. fluorecens; tambēm foram sensiveis E. coli, P. fragi e E. aerogenes. Alcaligenes viscolatis foi a mais resistente das bactérias testadas. As leveduras não foram inibi das. Os resultados encontrados por PINHEIRO et alii (1968), de que as substâncias produzidas por Leuconostoc citrovorum e Streptococcus dia$\underline{\text { cetylactis }}$ que inibiam a Pseudomonas fragi, eram mais ativas a um $\mathrm{pH} \underline{\text { a }}$ baixo de 5, coincidem com os obtidos dos experimentos, jä citados, de MATHER e BABEL (1959) e MARTH e HUSSONG (1963).

IANDOLA et alii (1965) mostram que em cultura mista de Streptococcus diacetylactis e Staphylococcus aureus estes ültimos foram inibidos por aqueles, provavelmente devido ao esgotamento de nutrientes.

PRICE e LEE (1970) encontraram que, algumas espécies de Pseudomonas eram inibidas pelo crescimento de lactobacilos, devido à produção de peroxido de hidrogênio.

DALY et alii (1970) determinaram que, em leite não gorduroso, $\underline{\text { s. }}$ lactis subesp. diacetylactis inibia espécies tais como:

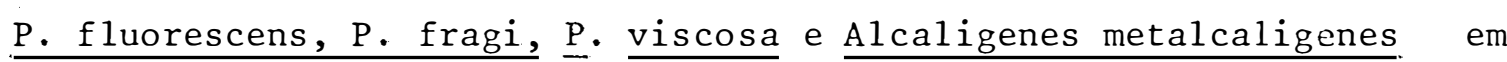
99\%; E. coli em 80\%; Salmonella tennesse em 70\%. A inibição de $\underline{\mathrm{S}}$. aureus foi de $99,98 \%$ a pH 4,5, sendo que não houve inibição a pH 6,8. 0LIVEIRA (1969 e 1970) comprovou que, tanto em placa de petri como em creme para produção de manteiga, $\underline{S}$. diacetylactis e $\underline{\text { L. }} \underline{\text { citrovorum exer }}$ cem inibição sobre $\underline{P}$. putrefaciens, evitando assim, o efeito proteolítico que esta poderia causar nesse produto 
SPECK (1972) estudou a interação entre culturas comer ciais de estreptococos láticos, usados como "starters" para queijos, e diferentes patógenos dos alimentos. Nele detectou que Salmonella galli

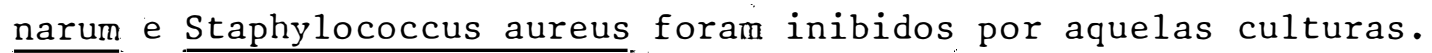

JUFFS e BABEL (1975) estudaram a inibição de bactērias psicrotróficas por $\underline{L}$. cremoris e $\underline{S}$. 1actis subesp. diacetylactis, concluindo que essà inibição é devida à produção de peróxido de hidro gênio por estes microrganismos o que reduz a velocidade de crescimen das bactérias psicrotróficas. Isto é importante para a permanência de um bom sabor, boas qualidades organolépticas e da capacidade de armaze namento sob refrigeração por um maior espaço de tempo (COUSIN e MARTH, 1977).

BABEL (1977) cita vários autores que estudaram os efeitos inibidores produzidos por certas bactérias láticas sobre outras. Estes autores mostram que, $\underline{S}$. 1actis é capaz de retardar o crescimento de $\underline{L}$. bulgaricus e, de inibir o crescimento de $\underline{\text { L }}$. casei. Também linhagens de $\underline{S}$. 1actis e $\underline{S}$. cremoris capazes de inibir outros estreptococos láticos e, inclusive, outras linhagens dessas mesmas espécies.

Muitos autores estudaram diversas culturas láticas e encontraram que as mesmas são produtoras de metabolitos com atividade antibiótica, como por exemplo: L. acidophilus produz acidophilin (VA KIL e SHAHANI, 1965), lactocilin (GROSSOWICS et alii, 1947), acidolin (HAMDAM e MIKOLASCIK, 1973) e lactocilin (KODAMA, 1952); L. plantarum. produz lactolin (KODAMA, 1952); L. brevis produz lactobrevin (AYEBO e SHAHANI, 1980); L. bulgaricus produz bulgaricin (REDDY e SHAHANI, 1971); 


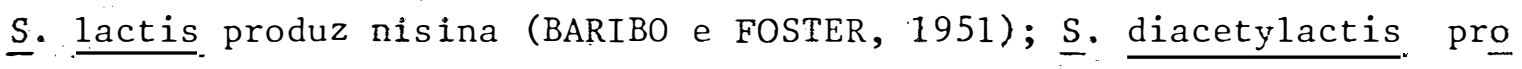
duz diplococcin (COLLINS, 1961) e $\underline{S}$. cremoris produz diplococcin (DAVEY e RICHARDSON, 1981).

Além destas substâncias antibióticas as culturas láti cas produzem outras substâncias de efeito inibidor para vārios micror ganismos. Assim, por exemplo, os ācidos produzidos pelas bactérias "starters" constituem um preservativo importante para os alimentos. Os ācidos diferem em sua habilidade de inibir o crescimento bacteriano (CHUNG e GOEPFERT, 1970). Embora o ācido 1ático seja o ācido predominantemente produzido pela maioria dos "starters" láticos, ele não è tão efetivo como o ácido acético na inibição do crescimento de outros microrganismos.

Apesar do ácido acético ser produzido em pequenas con centrações pelos "starters" láticos, ele tem uma ação inibidora efeti-

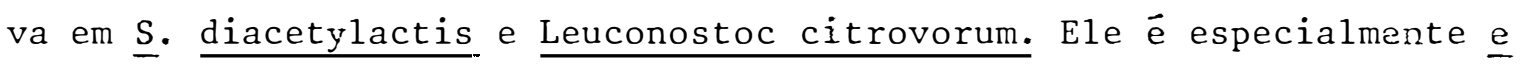
fetivo contra Pseudomonas fragi e Salmonella gallinarum (PINHEIRO et alii, 1968 e SORRELLS e SPECK, 1970).

PINHEIRO et alii (1968) encontraram que as substâncias inibidoras produzidas por esses dois microrganismos eram compos tas por um componente volátil, identificado como ácido acético e, uma fração residual composta por três àcidos similares a alguns dos ácidos do ciclo de Krebs; eles são os ácidos glioxílico, malônico e alfa-cetoglutārico. AYEBO e SHAHANI (1980) afirmam que a produção dos ácidos lá tico, acético e formico como produtos finais da fermentação do leite, 
resultam na alteração do $\mathrm{pH}$ do meio, o qual afeta adversamente as outras bactērias não àcido lāticas.

Uma outra substância inibidora é o peroxido de hidrogênio. DAHIYA e SPECK (1968) citam o Lactobacillus lactis e L. bulgaricus. como produtores de um fator inibidor identificado como peroxido de hidrogênio, o qual era capaz de inibir à $\underline{s}$. aureus. GILliLAND e SPECK (1977) observaram a ação antagônica de $\underline{L}$. acidophilus sobre pató genos entericos tais como Salmonella thyphimurium, Staphylococcus aureus, E. coli enteropatogênica e Clostridium perfrigens. COLLINS e ARA MAKI (1980) demonstraram que o L. acidophilus produz peroxido de hidro gênio suficiente para retardar o crescimento de Pseudomonas fragi.

Entre todas as culturas láticas, as mais pesquisadas são o L. acidophilus e o $\underline{L}$. bulgaricus, pela sua importância como ini bidores de microrganismos patógenos intestinais e bactérias deteriora doras de alimentos.

BRYAN (1965) em estudo, in vitro, demonstrou que $\underline{L}$. acidophilus e L. bulgaricus causam inibição de patógenos intestinais e de bactérias putrefactivas; e, como conclusão do seu trabalho afirma que, essas substâncias produzidas pelos lactobacilos devem ser as res ponsāveis pelo valor terapéutico atribuído ao leite acidófilo e ao io gurte. SHAHANI et alii (1976) comprovaram a capacidade de 12 linhagens de L. acidophilus e 3 linhagens de L. bulgaricus para inibir, em diferentes meios de cultura, as seguintes bactérias: Bacillus subtilis, Serratia marcescens, Pseudomona aeruginosa, E. coli, Streptococcus 1 1ac- 
ti.s e Staphylococcus aureus. Além disso L. acidophilus demonstrou eficiência no combate a vários patógenos dos gêneros Salmonella, Shigella,

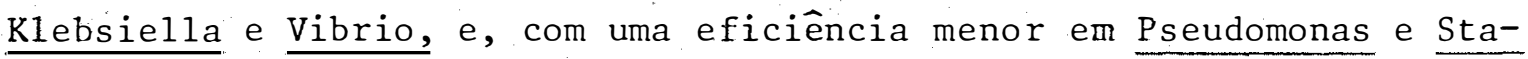
phylococcus. A temperatura ótima para a produção do antibiótico foi de $37^{\circ} \mathrm{C}$ para L. acidophilus e $50^{\circ} \mathrm{C}$ para L. bulgaricus.

Tanto SHAHANI et alii (1976) como REDDY et alii (1984) inocularam $\underline{L}$. acidophilus e $\underline{\text { L }}$ bulgaricus em diferentes meios de cultu ra e encontraram que eles apresentam sua máxima atividade antibacteria na no leite, o qual demonstra que este possui nutrientes essenciais pa ra os microrganismos produzirem compostos inibidores. Esses mesmos au tores encontraram que ambos os microrganismos produzem substâncias an tibacterianas para microrganismos Gram + e Gram -, incluindo espécies patogênicas, mas, aparentemente, não tem atividade antifungica. SHAR-

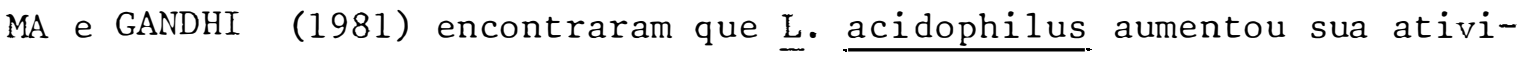
dade antibacteriana quando foi inoculado em cultura mista (junto com S. lactis) mais que quando inoculado em cultura pura. SHAHANI et alii (1977) propõe que o acidophilin, devido à sua importante atividade an tibacteriana, talvez possa ser usado para previnir ou retardar o crescimento de bactērias indesejāveis no alimento, equipamento e embalagens.

YAZICIOGLU e YILMAZ (1966) estudaram a microflora do iogurte e sua ação antimicrobiana. Neste experimento, iogurte fresco e iogurte armazenado por um mês, mostraram possuir a mesma ação antibacteriana sobre patögenos resistentes a determinados antibiōticos. 
TODOROV (1962) e MEL'NIKOVA e KORELEVA (1975) conclui ram que, tanto $\underline{S}$. thermophilus como o L. bulgaricus produziam substâncias que inibiam a Salmonella e E. coli e que o poder inibidor de $\underline{\text { L. }}$

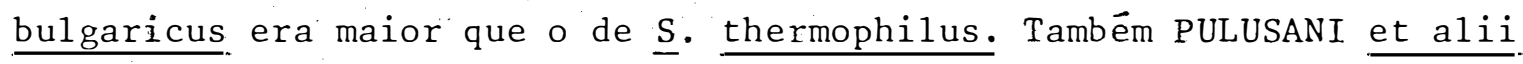
(1979) encontraram atividade antimicrobiana em ambos os microorganismos, e, extrairam, da cultura de $\underline{S}$. thermophilus, metanolacetona como a substância responsāvel por essa atividade. Ao conträrio deles, SHINGH et alii (1979), utilizando líquido filtrado de culturas de $\underline{\text { S. }}$ thermo-

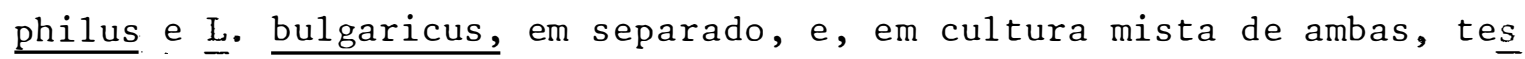
taram a sua atividade antibacteriana com $\underline{E}$. coli, $\underline{\text { S }} \underline{\text { aureus, }} \underline{\text { P. fragi }}$. e Micrococcus flavus. O filtrado proveniente de $\underline{S}$. thermophilus, não mostrou atividade antimicrobiana para nenhum desses microrganismos. 0 filtrado de $\underline{L}$. bulgaricus causou pronunciada inibição em todas as bactérias testadas, enquanto que o filtrado da cultura mista apresentou uma inibição ainda maior. Estas observações acentuam o provável papel

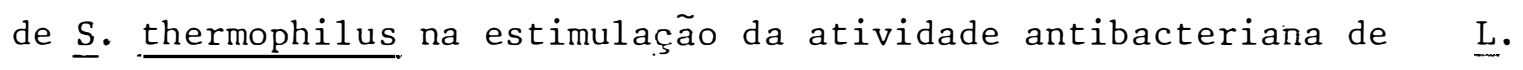
bulgaricus na cultura mista.

RUBIN et alii (1982) encontraram que o ácido lático $\underline{i}$ nibe o crescimento de Salmonella typhimurium em iogurte. Eles encontra ram, tambēm, que a inibição pelo àcido 1ático era irreversível. o refe rido àcido entra na célula em estado não dissociado, mas, uma vez den tro da mesma, ele se dissocia, pois, o pH intracelular é maior que o pH extracelular. A forma dissociada (anión lactato) acumula-se na célu la pois, nessa forma, não pode sair dela, consequentemente, abaixa o 
$\mathrm{pH}$, inibindo, assim, o metabolismo celular. Estes autores demonstraram

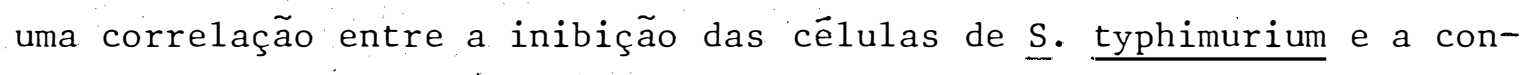
centração intracelular do ácido 1ático na forma dissociada, fato que concorda com o encontrado por WEINER e DRASKOCZY (1961).

3.4. Efeitos das Culturas Láticas na Fermentação do Leite e sua Influência na Qualidade do Iogurte.

Na produção dos derivados do leite são adicionadas as culturas láticas por dois motivos: a produção de ácido lático e a pro dução do aroma desejado (COLLINS, 1962). Segundo as classificações pro postas por KOSIKOWSKI (1970) e PONCE e PIÑEYRO (1974), as culturas 1á ticas utilizadas no presente trabalho pertencem a três grupos: 1) os produtores de ácido (Streptocccus thermophilus e Lactobacillus acidophilus); 2) produtores de ácido, sabor e aroma (Lactobacillus bulgaricus e Streptococcus lactis subesp. diacetylactis) e 3) produtores de sabor e aroma (Leuconostoc cremoris).

A obtenção de um iogurte de boa qualidade depende, em grande parte, das culturas 1áticas usadas, portanto, sua escolha converte-se em importante fator para a obtenção de um produto final de ca racterísticas desejáveis. KURMANN(1977) cita certos fatores que devem ser considerados no momento de se usar tais culturas. Esses fatores são: poder acidificante, pós-acidificação, produção do aroma, produção de mucus (capsular) e proteolise. 
1. Poder acidificante: o uso de culturas de poder acidificante médio ou baixo é o mais adequado para evitar a pósacidificação durante o resfriamento, armazenamento e dis tribuição do iogurte.

2. Pós-acidificação: è a acidez produzida após o período de incubação. A pós-acidificação ê menor quando o poder ací dificante das culturas é mais fraco.

3. Produção de aroma: os lactobacilos e alguns estreptococos produzem compostos aromáticos que são os responsáveis pelo aroma típico do iogurte.

4. Produção de mucus: a produção de mucus melhora a viscosidade e a consistência do iogurte.

5. Proteólise: o poder proteolítico das culturas láticas é importante. Uma proteólise moderada é interessante e ne cessāria, porēm, uma atividade proteolítica muito forte pode produzir defeitos graves.

Do uso de culturas láticas com um adequado equilíbrio desses cinco fatores mencionados, é que se pode obter um iogurte de boa qualidade.

Segundo KROGER (1976) a consistência do iogurte é, pro vavelmente, tão importante como seu sabor e aroma. Uma firmeza adequa- 
da sem separação de soro (syneresis) è essencial para a obtenção de um produto de alta qualidade. A separação do soro indica uma fermentação inadequada e sabores estranhos. Este é o problema físico mais importan te relacionado à consistência e textura do iogurte (HUMPHREYS e PLUNKETT, 1969; KROGER, 1976).

o iogurte è um gel firme e fino, resultante da transformação da lactose em ácido 1ático, o que ocasiona a queda do $\mathrm{pH}$ e causa progressiva solubilização do fosfo-citrato de cálcio e agregação da caseina (GREEN, 1980). A consistência do iogurte está relacionada com sua acidez (O'NEIL et alii, 1979) e esta ültima muda durante o ar mazenamento, em menor ou maior grau, dependendo da acidez inicial do produto e da temperatura (SALJI e ISMAIL, 1983).

Embora certo grau de acidez seja desejável no iogurte, uma acidificação excessiva do mesmo é indesejāvel, visto que conduz à separação do soro e deterioração da sua consistência e viscosidade (WOLFSCHOON-POMBO et alii, 1983). Segundo NIELSEN (1976) obtém-se um coagulo firme uma vez alcançado um $\mathrm{pH}$ de 4,6-4,7 e segundo KROGER (1976) quando este $\bar{e}$ de 4,4 , pois um $\mathrm{pH}$ final acima de 4,5 resulta em un coágulo fraco. Outros pesquisadores estudaram este problema e assim HUMPHREYS e PLUNKETT (1969) recomendam um pH final de 3,7 - 3,8; KOSI KOWSKI (1970) 4,4; SELLARS e BABEL (1970) 4,0, enquanto que LÜCK e MOSTERT (1971) afirmam que um iogurte com pH final de 3,9 - 4,1 não é agradável devido a sua alta acidez. 
Segundo diversos autores (GALESLOOT e HASSING, 1973; GROUX, 1973 ; HUMPHREYS e PLUNKETT, 1969; KROGER, 1976; NIELSEN, 1976 e WOLFSCHOON-POMBO et alii, 1983) a consistência do iogurte é função do: teor de sólidos do leite; tratamento térmico do leite prévio à ino culação; uso de culturas "starters" de ação proteolítica (da caseina) Iigeira; acidificação adequada e de suficiente produção de mucus capsu lar; da temperatura de incubação correta; do manuseio do iogurte depois da coagulação e das condições de armazenamento.

A viscosidade bacteriana é causada por algumas cultu ras láticas que produzem um polissacarideo (mucus) durante a fermentação, o qual melhora a viscosidade do iogurte (GALESLOOT e HASSING,1966; TAMIME e ROBINSON, 1978 ; TAMIME, 1978a e b; LUCZYNKA et al, 1978). Se gundo MARTINELLI filHo (s.d.) a produção dessa secreção mucosa é favorecida pela incubação a temperaturas baixas. SHARPE et al (1972) e TA MIME (1977a e 1978b) informam que o mucus segregado pelas espécies he terofermentativas do gênero Lactobacillus é uma glucana, provavelmente um dextraneo. Segundo DAVIS (1975) os Leuconostoc são os microrganis mos läticos mais adequados para obter-se uma viscosidade apropriada.

Ultimamente tem-se dado importância à produção de pró dutos läcteos mediante o uso de acidificantes e aromatizantes químicos, porém estes têm o problema de necessitar dos atributos naturais que so mente são produzidos pelas culturas láticas (HEMPENIUS e LISKA, 1964).As sim, para a produção do iogurte, o leite pode ser acidificado diretamente, sua consistência e textura são essencialmente similares, mas 0 
sabor do iogurte obtido pela acidificação dos microrganismos láticos é muito melhor que o do acidificado diretamente (KILARÁ e SHAHANI, 1978).

$$
\text { DUTTA et al (1971) afirmamque as bactérias láticas }
$$

têm uma ação proteolítica fraca, enquanto GROUX (1976) afirma que ela é suficiente para produzir mudanças na estrutura física do produto e contribuir para a produção de compostos aromáticos e do sabor. Os pro dutos da proteólise, peptidos de vários tamanhos e aminoácidos, raramente contribuem diretamente com o sabor e aroma, mas são precursores de uma variedade de reações químicas e enzimáticas que produzem os conn postos.do sabor e aroma (VIANI e HORMAN, 1976). Assim os estreptococos 1áticos podem produzir acetaldeido por desdobramento da treonina e da glicina (KEENAN e BILLS, 1968; LEES e JAGO, 1976a e 1976b; SANDINE e ELLIKER, 1970; VERINGA, 1973), e L bulgaricus pode produzir acetaldei do pelo desdobramento da treonina (HUMPHREYS e PLUNKETT, 1969; SANDINE e ELLIKER, 1970; VERINGA, 1973). O poder proteolítico das culturas lá ticas é importante pelo fato de que uma proteólise muito forte pode pro duzir defeitos como: diminuir a consistência do iogurte; favorecer re lação de protocoperação entre os microrganismos 1áticos usados e assim, produzix uma acidificação excessiva, podendo provocar também o a parecimento de um sabor amargo (KurmanN, 1977).

o sabor e o aroma do iogurte dependem, quase exclusivamente, das culturas láticas usadas e do seu metabolismo durante a in cubação (KROGER, 1976). Segundo KEENAN e BILLLS (1968), KROGER (1976), SHARPE (1979) e TAMIME e DEETH (1980) o ácido lático produzido pelas 
culturas "starters", durante a fermentação do leite, não tem odor e não influi no aroma, mas é considerado como sendo o responsável pelo sabor ácido e fresco do iogurte. Os microrganismos das culturas láticas produzem outros compostos carbonados voláteis tais como acetaldeido, diacetil, acetoin e ácidos orgânicos voláteis, importantes na pro dução de aroma e sabor (diferente do ácido lático) no iogurte.

PETTE e LOLKEMA (1950) foram os primeiros a assinalar o fato de que o acetaldeido era o componente mais importante do aroma do iogurte, e demonstraram que era produzido pelos lactobacilos. HARVEY (1960) e BOTTAZZI e DELLAGLIo (1967) observaram que os estreptococos láticos também podem produzir pequenas quantidades de acetaldeido. MUTAI et al, 1972; DUTTA et al, 1973 e BAISYA e BOSE, 1975 assinalaram que, além do acetaldeido, também è importante a presença de diacetil e acetoin.

Outros compostos que são complementos dos anteriores na formação do aroma são a acetona produzida pelos lactobacilos (BOT TAZZI e VESCOVO, 1969), äcidos orgânicos voláteis como o ácido acético formado por hidrólise da caseina pelos lactobacilos (NAKAE e ELLIOTT, 1965) e os ácidos acético e oxalacético, formados pelo streptococcus

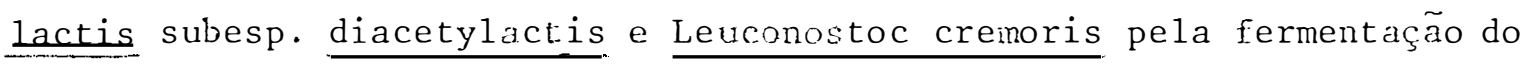
citrato (HARVEY e COLLINS, 1961).

Segundo KILARA e SHAHANI (1978) a lactose e o citrato do leite são fermentados durante a incubação do iogurte e convertidos em um composto intermediário chave, o piruvato. Este, por sua vez, po- 
de ser transformado em ácido lático, principalmente pelos microrganis mos do grupo 1 (Streptococcus termophilus e Lactobacillus acidophilus) e também do grupo 2 (Lactobacillus bulgaricus e Streptococcus lactis subesp. diacetylactis) ou em compostos aromáticos como acetaldeido e

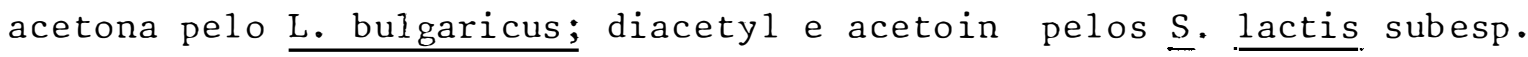
diacetylactis e Leuconostoc. 
4. MATERIAIS E METODOS

\subsection{Materiais}

4.1.1. Culturas Läticas

As culturas läticas utilizadas para a produção do io gurte foram as seguintes:

\footnotetext{
- Lactobacillus bulgaricus NCDO 1429

- Streptococcus thermophilus NCDO 489

- Lactobacillus acidophijus ATCC (s/n)

- Streptococcus lactis var. diacetylactis NCDO 176

- Leuconostoc cremoris (citrovorum) ATCC 19433
} 


\subsubsection{Leite}

o leite utilizado neste experimento foi obtido do re banho Leiteiro do Departamento de Zootecnia da ESALQ. 0 mesmo foi pas teurizado e padronizado para teor de sólidos por adição de leite em pó desnatado.

\subsection{Métodos}

4.2.1. Combinações de Culturas

o leite foi inoculado com as seguintes combinações de culturas láticas:

Iogurte Tipo I: L. bulgaricus + S. thermophilus

$$
(2,0 \%+2,0 \%)
$$

Iogurte Tipo II: $\underline{\text {. }}$ bulgaricus $+\underline{S}$. thermophilus $+\underline{\text { L }}$ acidophilus

$$
(1,5 \%+1,5 \%+1 \%)
$$

Iogurte Tipo III: $\underline{\text { L }}$ bulgaricus $+\underline{\text { S }}$ thermophilus $+\underline{\text { S. lactis var. dia- }}$

$$
(1,5 \%+1,5 \%+1 \%)
$$

Iogurte Tipo IV: L. bulgaricus $+\underline{S}$. thermophilus + L. cremoris

$$
(1,5 \%+1,5 \%+1 \%)
$$




\subsubsection{Condições dos Experimentos}

Teor de sôlidos do leite: 14\%

- Temperatura de pasteurização: $85^{\circ} \mathrm{C} \pm 0,5$

- Tempo de pasteurização: 30 minutos

- Resfriamento do leite pasteurizado em água corrente até $42^{\circ} \mathrm{C} \pm 0,5$

- Teor de inóculo: $4 \%$

- Temperatura de incubação: $42^{\circ} \mathrm{C} \pm 0,5$

- Tempo de incubação: 4 horas

- Resfriamento rápido com gelo até o coagulo obter a temperatura de $7^{\circ} \mathrm{C} \pm 0,5$

- Armazenamento do produto a temperatura de $4^{\circ} \mathrm{C} \pm 0,5$

\subsubsection{Preparo do iogurte}

o teor de sólidos do leite crú foi determinado e acer tado para $14 \%$ por adição de leite em pó desnatado. Foi pasteurizado a $85^{\circ} \mathrm{C}$ durante 30 minutos e rapidamente resfriado com ägua corrente até $42^{\circ} \mathrm{C}$. Após isso foi inoculado rom $4 \%$ da combinação de culturas deseja da e colocado a incubar a $42^{\circ} \mathrm{C}$ durante 4 horas. Para cada tipo de iogurte, em cada um dos 6 ensaios, foram produzidos 5 1itros de iogurte incubados em frascos de $120 \mathrm{ml}$. Imediatamente após a incubação esses frascos foram resfriados rapidamente em banho de gelo até obter uma temperatura de $\pm 7^{\circ} \mathrm{C}$. Depois colocados em refrigerador a uma temperatu ra de $\pm 4^{\circ} \mathrm{C}$ e armazenados por 30 dias. 


\subsubsection{Anātises Realizadas}

\section{$4.2 \cdot 4.1 . \mathrm{pH}$}

$\Delta$ determinação do pH foi feita logo após o resfriamen to do coágulo, e por ocasião da realização de cada uma das provas de degustação utilizando um potenciômetro digital marca Digimed DMPH 2 . Com os valores do pH obtidos (dois em cada ocasião) foram calculadas as médias.

\subsubsection{Anälise Sensorial}

\subsection{Painel de Degustadores}

Para a realização das anālises sensoriais ou provas de degustação necessitou-se, antes, selecionar e treinar os integrantes do referido painel.

Foram aplicados testes de seleção visando conhecer a capacidade natural dos degustadores em diferenciar soluções para cada um dos quatro sabores básicos e, qual a concentração mínima que eram capazes de detectar. Para isso foram aplicados testes de sensibilidade, "Threshold" (ficha päg. 38), para cada um dos sabores bāsicos (ácido,a inargo, doce e salgado), segundo o método de DAWSON et alii (1963).

Os degustadores selecionados nesta fase preliminar fo ram submetidos a testés de seleção sensorial, do tipo triangular (ficha päg. 39), aplicados segundo o método de MORI et alii (1983), com a finalidade de confirmar a habilidade demonstrada pelos provadores. 
TESTE DE SENSIBILIDADE (THRESHOLD)

NOME: DATA :

1. Indique qual dos 4 gostos básicos (ácido, amargo, doce, salgado) está presente nas amostras apresen tadas.

2. Indique em qual das amostras o identificou pela primeira vez .

Nọ da Amostra

1)

2)

3)

4)

5)

6)

. 
NOME:

DATA :

Duas amostras são iguais e uma è diferente. Coloque um círculo ao redor da amostra diferente em cada grupo.

Grupo

Nümero de Amostras

1

2

3

Comentārios: 
As amostras apresentadas aos degustadores foram numeradas segundo o método de MORI et alii (1983).

A partir dos resultados dos testes aplicados, os meThores degustadores foram treinados segundo diretivas dadas por DAWSON e HARRIS (1951), especialmente para a degustação do iogurte.

\subsection{Provas de Degustação}

As provas de degustação foram feitas dentro das primeiras 24 horas apōs o iogurte ser produzido, 15 dias e 30 diás após sua produção. Estes tempos foram determinados com base em experinentos preliminares de variação do $\mathrm{pH}$ ao longo do armazenamento e também cm um interesse industrial $€$ comercial.

Os degustadores treinados, num total de 6 , realizaram as provas de degustação utilizando-se de uma ficha de avaliação do ti po Escala Estruturadá (pág. 41), adaptacia do modelo de ficha estrutura da por PEARCE e HEAP (1974), onde foram avaliadas todas as características do iogurte. Os outros degustadores selecionados, num total de 15, não foram treinados e simplesmente preencheram uma ficha, de preferência do tipo Escala Hedônica (pāg. 42), segundo o modelo apresentado por CHAIB DE MORAES (1983).

Os 4 tipos de combinações de culturas läticas foram comparadas em seis ensaios, onde as amostras foram apresentadas aos pa res e, assim, comparados todos os tipos entre si. 
ESCALA ESTRUTURADA

NOME:

DATA:

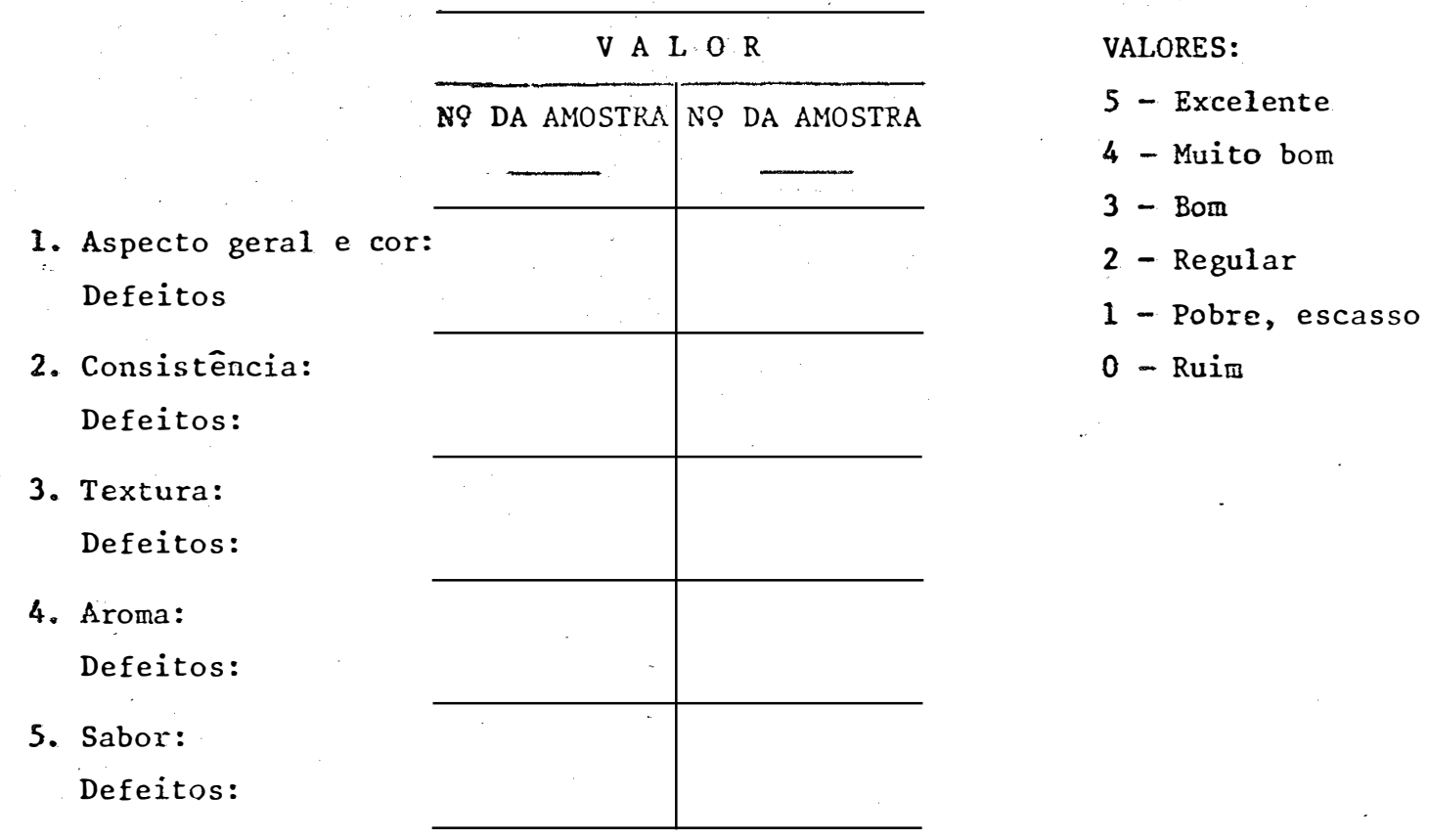

6. Comentários: Nọ DA AMOSTRA :

NO DA AMOSTRA :

VOCABULARIO SUGERIDO PARA AVALIAR AS PROPRIEDADES E DEFEITOS EM IOGURTE:

Propriedades

\section{Defeitos}

1. Aspecto geral e cor

Materiais estranhos, falta de uniformi dade, cor estranha, descoloração super ficial, com separação de soro, cora sé paração de gordura, com presença de gás.

2. Consistência

Firme Muito fluida, muito dura.

3. Textura

Lisa, suave, uniforme

Gelatinosa, limosa (slimy), aspera, gra nulosa ou com grumos.

4. Aroma

A prodito fresco, agradāvel Estranho, desagradável, gasificado

5. Sabor

Sujo, amargo, muito ácido, muito doce, insipido. 
42.

\title{
ESCALA HEDÕNICA
}

Nome:

DATA :

Avalie cada amostra usando a escala abaixo para descrever o quanto você gostou ou desgostou.

\author{
1. Desgostei Muitíssimo \\ 2. Desgostei Muito \\ 3. Desgostei Moderadamente \\ 4. Desgostei Ligeiramente \\ 5. Indiferente \\ 6. Gostei Ligeiramente \\ 7. Gostei Moderadamente \\ 8. Gostei Muito \\ 9. Gostei Muitíssimo
}

Número da Amostra

"Valor

Comentärios: 


\subsubsection{AnāTise Estatística}

o esquema da anālise estatística utilizado foi o de blocos incompletos balanceados do tipo V, segundo COCHRAN e COX (1957). Foi realizada, com os dados fornecidos pelos degustadores nas fichas da escala estruturada e hedônica, uma análise de variância segundo o modelo

$$
y_{i j}=m+t_{i}+r_{j}+(b / r)_{i j}+e_{i j},
$$

não tendo sido encontrada nenhuma diferença significativa. Devido a es te fato, só foi possível utilizar os dados da escala estruturada, ana lisando-se separadamente cada um dos cinco itens avaliados pelos degus tadores. Isso foi feito através de uma anālise de variância não paramé trica, no esquema de blocos incompletos balanceados, segundo SHIROSE (1982), utilizando o teste de DURBIN (1951); testou-se, então, a hipótese de nulidade de que os tratamentos não diferem entre si, contra a alternativa de que pelo menos dois tratamentos diferem entre si, utili zando-se a extensão do teste de "Friedman" (GUIDONI, 1978) no caso de ocorrência de empates. 


\section{RESULTADOS E DISCUSSÃO}

\subsection{Resultados}

As somas de pontos conferidos pelos degustadores no julgamento das propriedades organolépticas (análise sensorial) são en contradas nas tabelas I, II e III; as médias dos valores do $\mathrm{pH}$ na tabe Ia IV e o resultado da análise de variancia encontra-se na tabela V.

Destes resultados constatou-se que estes quatro tipos de iogurte comportaram-se, de acordo com os atributos avaliados, da se guinte maneira.

\subsubsection{Aspecto Geral e Cor}

Quanto ao aspecto geral e a cor os quatro tipos de io gurte comportaram-se de forma semelhante, pois os tratamentos náo apre sentaram diferença significativa nem ao começo do período de armazena- 
mento (24 horas), nem ao final do mesmo (30 dias). Embora nesses dois períodos não tenha havido diferença significativa, esta ocorreu aos 15 dias de armazenamento onde o iogurte tipo IV foi o que somou maior nu mero de pontos (15), sendo tambēm o melhor qualificado logo no início, ou seja, após 24 horas de produzido. Aos 30 dias, o iogurte tipo IV juntamente com o tipo II foram os que maior número de pontos somaram pa ra as características aspecto geral e cor.

\subsubsection{Consistência}

Com respeito à consistência, os iogurtes apresentaram diferença sifnigicativa para os três períodos de armazenamento (24 ho ras, 15 e 30 dias) e sempre o iogurte tipo IV foi o que obteve maior soma de pontos.

\subsubsection{Textura}

Em relação ao atributo textura, após 24 horas de arma zenamento, os quatro tipos de iogurte mostraram-se semelhantes, não ha vendo diferença significativa entre os mesmos, sendo os melhores quali ficados os tipos II e IV, com um total de 15 pontos cada um. Por outro lado, após 15 e 30 dias de armazenamento a diferença foi significativa ao nível de $1 \%(\mathrm{P}<0,01)$, sendo que o iogurte tipo IV recebeu o maior número de pontos nos dois casos (15 e 15). 


\subsubsection{Aroma}

O aroma foi uma das características que menos variou durante o período estudado, tendo apresentado diferença significativa entre os quatro tipos de iogurtes experimentados somente aos 30 dias de armazenamento. Neste atributo, também o iogurte tipo IV foi o meIhor qualificado com um total de 15 pontos. Embora a diferença entre os tipos de iogurtes não tenha sido significativa às 24 horas e aos 15 dias de armazenamento, no primeiro caso (24 horas) os melhores qualifi cados foram os iogurtes tipo II e IV, com um total de 15 pontos: cada um. No. segundo caso, o iogurte tipo IV foi o melhor qualificado recebendo um total de pontos (15) bem superior aos demais.

\subsubsection{Sabor}

Quanto à propriedade organolēptica sabor, também a di ferença entre os tipos de iogurtes foi significativa somente aos 30 dias de armazenamento e aqui novamente o tipo IV foi o que maior soma de pontos (14) recebeu. Apesar da diferença não ter sido significativa às 24 horas após a elaboração, os tipos II e IV foram os que obtiverạm maior soma de pontos (15) e aos 15 dias o iogurte tipo IV foi o melhor qualificado, tendo recebido a maior soma de pontos (14). 
De acordo com as observações feitas pelos degustadores nas fichas de escala estruturada, encontrou-se que os iogurtes com 24 horas de armazenamento nao apresentavam maiores problemas, com exce ção do iogurte tipo II que apresentou-se um pouco fluido. Aos 15 dias alguns dos iogurtes começaram a apresentar leves defeitos, tais como: o iogurte tipo I tinha sabor lático fraco, um pouco ácido e amargo; o iogurte tipo II possuia consistência fluida, sabor um pouco äcido e amargo; o iogurte tipo III apresentou sabor lático fraco e um pouco áci do. Aos 30 dias esses defeitos foram mais marcantes. O iogurte tipo I apresentou-se mais ácido; o iogurte tipo II mais ácido e amargo e, o tipo III adocicado. O iogurte tipo IV em geral não apresentou defeitos, salvo aos 30 dias onde em alguns poucos casos foi detectado um sabor levemente ācido. 
TABELA I - Anālise sensorial dos iogurtes com 24 horas de armazenamento.

Total de Pontos (*)

\begin{tabular}{lcccc}
\hline \multicolumn{1}{c}{ Iogurte Tipo $(* *)$} & I & II & III & IV \\
\hline Item & 14 & 13 & 11 & 15 \\
1. Aspecto Geral e Cor & 12 & 12 & 11 & 15 \\
2. Consistência & 13 & 15 & 12 & 15 \\
3. Textura & 14 & 15 & 14 & 15 \\
4. Aroma & 14 & 15 & 12 & 15 \\
5. Sabor & & & & 15 \\
\hline
\end{tabular}

(*) Soma total dos pontos conferidos pelos degustadores

(**) Iogurte tipo I (L. bulgaricus $+\underline{S}$. thermophilus)

Iogurte tipo II (L. bulgaricus $+\underline{S}$. $\underline{\text { thermophilus }}+\underline{L}$. acidophilus)

Iogurte tipo III (L. bulgaricus $+\underline{S}$. thermophilus $+\underline{\text { S. lactis var. }}$ diacetylactis)

Iogurte tipo IV(L. bulgaricus ${ }^{2} \underline{S}$. thermophilus $+\underline{L}$. cremoris $)$ 
TABELA II - Anālise sensorial dos iogurtes com 15 dias de armazenamento.

Total de Pontos (*)

\begin{tabular}{lcccc}
\hline \multicolumn{1}{c}{ Iogurte Tipo $(\stackrel{\sim}{*} *)$} & I & II & III & IV \\
Item & 12 & 13 & 14 & 15 \\
\hline 1. Aspecto Geral-e Cor & 10 & 10 & 12 & 15 \\
2. Consistência & 10 & 10 & 12 & 15 \\
3. Textura & 12 & 12 & 12 & 15 \\
4. Aroma & 10 & 10 & 13 & 14 \\
5. Sabor & & & & \\
\hline
\end{tabular}

(*) Soma total dos pontos conferidos pelos degustadores

$\left(x^{*}\right)$ Iogurte tipo I (L. bulgaricus $+\underline{S} \cdot \underline{\text { thermophilus })}$

Iogurte tipo II (I. bulgaricus $+\underline{S} \cdot \underline{\text { thermophilus }+\underline{\text { L. }} \text { acidophilus) }}$

Iogurte tipo III (L. bulgaricus $+\underline{S}$. thermophilus $+\underline{\text { S. lactis var. }}$ diacetylactis)

Iogurte tipo IV (L. bulgaricus + S. thermophilus + L. cremoris) 
TABELA III - Anälise sensorial dos iogurtes com 30 dias de armazenamen to.

Total de Pontos (*)

\begin{tabular}{lcccc}
\hline \multicolumn{1}{c}{ Iogurte Tipo $(* *)$} & I & II & III & IV \\
Item & 12 & 14 & 12 & 14 \\
\hline 1. Aspecto Geral e Cor & 12 & 14 & 11 & 15 \\
2. Consistência & 12 & 14 & 11 & 15 \\
3. Textura & 11 & 14 & 9 & 15 \\
4. Aroma & 11 & 11 & 7 & 14 \\
5. Sabor & & & & \\
\hline
\end{tabular}

(*) Soma total dos pontos conferidos pelos degustadores

$(* *)$ Iogurte tipo I (L. bulgaricus $+\underline{S}$. thermophilus)

Iogurte tipo II (‥ bulgaricus $+\underline{S}$. thermophilus $+\underline{L}$. acidophilus)

Iogurte tipo III (L. bulgaricus $+\underline{S}$. thermophilus $+\underline{S}$. lactis var. diacetylactis)

Iogurte tipo IV (L. bulgaricus $+\underline{S}$ thermophilus $+\underline{L}$ cremoris) 
TABELA IV - Médias dos valores de $\mathrm{pH}$.

$\mathrm{pH}(*)$

\begin{tabular}{|c|c|c|c|c|}
\hline $\begin{array}{l}\text { Tipo de Iogurte (** } \\
\text { Tempo de } \mathrm{Ar}- \\
\text { mazenamento }\end{array}$ & I & I I & III & IV \\
\hline $\begin{array}{l}\text { Apōs incubação e Refrige } \\
\text { ração }\end{array}$ & 4,6 & 4,7 & 4,7 & 4,6 \\
\hline 24 horas & 4,5 & 4,6 & 4,6 & 4,5 \\
\hline 15 dias & 4,3 & 4,3 & 4,5 & 4,3 \\
\hline 30 dias & 4,1 & 4,1 & 4,3 & 4,1 \\
\hline
\end{tabular}

(*) Médias de quatro repetições.

$(* *)$ Iogurte tipo I (L. bulgaricus $+\underline{S}$. thermophilus)

Iogurte tipo II (L. bulgaricus $+\underline{S} \cdot \underline{\text { thermophilus }}+\underline{L}$. acidophilus) Iogurte tipo III (L. bulgaricus $+\underline{\text { S. thermophilus }}+\underline{\text { S. lactis var. }}$ diacetylactis)

Iogurte tipo IV (L. bulgaricus $+\underline{S}$ thermophilus $+\underline{\text { L. cremoris }})$ 
52.

TABELA V - Anālise de Variância.

\begin{tabular}{lccc}
\hline Tempo de: Armazenamento & 24 Horas & 15 Dias & 30 Dias \\
Item & n.s. & $* *$ & $\mathrm{n} . \mathrm{s}$. \\
1. Aspecto Geral. e Cor & $* *$ & $* *$ & $* *$ \\
2. Consistência & $\mathrm{n} \cdot \mathrm{s}$. & $* *$ & $* *$ \\
3. Textura & $\mathrm{n} \cdot \mathrm{s}$. & $\mathrm{n} . \mathrm{s}$. & $* *$ \\
4. Aroma & $\mathrm{n} \cdot \mathrm{s}$. & $\mathrm{n} . \mathrm{s}$. & $*$ \\
5. Sabor & &
\end{tabular}

$$
\begin{aligned}
& \text { n.s. = não significativo } \\
& * * \text { = significativo ao nível de } 1 \%
\end{aligned}
$$




\subsection{Discussão}

A consistência fluida apresentada pelo iogurte tipo II pode ter vários motivos, tal como encontrado na bibliografia. Segundo KURMANN (1977) uma atividade proteolítica muito forte, das culturas lá ticas, poderia provocar um enfraquecimento da consistência do iogurte. Porém, segundo HuMPHREYS e PLUNKETT (1969) o coāgulo do iogurte se for ma com a precipitação completa da proteina quando obtido um $\mathrm{pH}$ de 4,6, e, segundo KROGER (1976), um pH final acima de 4,5 resulta em um coágu 1o fraco. Considerando o afirmado por estes autores também pode ser que seja devido à falta de uma acidez adequada, pois seu valor de $\mathrm{pH}$ foi um pouco alto $(4,7)$, embora o iogurte tipo III tenha apresentado o mesmo valor de $\mathrm{pH}$, mas com uma consistência firme.

A diminuição no sabor lático apresentado pelo iogurte tipo I e III aos 15 dias de armazenamento, talvez possa ser explicado pelo encontrado por HAMDAM et alii (1971) que, estudando a produção de acetaldeido em culturas comerciais, acharam que em duas delas, depois de duas semanas de armazenamento do produto a uma temperatura de $4^{\circ} \mathrm{C}$ o teor de acetaldeido caiu de 26 ppm para 14 e 10 ppm.

0 defeito do sabor ácido apresentado pelos iogurtes tipo I, II e III aos 15 dias e pelos iogurtes I e II aos 30 dias de ar mazenamento, são explicados por vários autores. Assim, RASIC e KURMANN (1978) afirmam que do ponto de vista técnico, a protocoperação bac teriana do iogurte pode produzir efeitos indesejáveis, como por exem- 
plo uma acidificação excessiva do iogurte, se ela não for apropriadamente controlada. KURMANN (1977) comprovou que num iogurte muito ácido, o sabor do ácido lático predomina, mas, por meio de um sabor ācido-a margo. SALJI e ISMAIL (1983) estudaram as mudanças do $\mathrm{pH}$ em iogurte ar mazenado em refrigeração. Essa acidez muda durante o armazenamento, em maior ou menor grau, dependendo da acidez inicial do produto, da tempe ratura de refrigeração e do poder de pós-acidificação das culturas. Es ses autores encontraram que, em iogurtes mantidos em refrigeração a $4^{\circ} \mathrm{C}$, as amostras com acidez inicial baixa ( $\mathrm{pH}$ alto 4,5 ) foram as que apresentaram o maior incremento na sua acidez e passaram de $\mathrm{pH}$ 4,5 pa ra $\mathrm{pH} 4,1$, enquanto que as amostras de acidez inicial alta ( $\mathrm{pH}$ baixo 3,9) permaneceram mais estáveis e passaram de $\mathrm{pH} 3,9$ a $\mathrm{pH}$ 3,7. Eles também comprovaram que as mudanças na acidez foram máximas na prí meira semana e mínimas depois. Se se compara os valores de $\mathrm{pH}$ por eles obtidos com os apresentados no presente trabalho, aprecia-se que, com exceção do iogurte tipo III que apresentou um $\mathrm{pH}$ um pouco elevado ao final do período de armazenamento, os outros três iogurtes apresentaram uma atividade de pós-acidificação normal. Porēm, segundo Lück e MOSTERT (1971), um iogurte com pH final de 3,9-4,1 não ë agradāvel ao paladar, devido a sua alta acidez, fato que foi assinalado pelo painel de degustadores, na prova de degustação feita aos 30 dias de armazenamento, para os iogurtes tipo I e II. No iogurte tipo IV este defej.to a presentou-se quase imperceptível. 
o defeito sabor amargo apresentado pelos iogurtes tipo I, II e III aos 15 dias e, pelos iogurtes I e II aos 30 dias de armazenamento, segundo KROGER (1976) e RENZ e PUHAN (1975), é devido à presença de peptidos de sabor amargo, cuja presença no iogurte é atribuída à proteōlise que o $\underline{L}$. bulgaricus realiza durante o armazenamento. Segundo PERRY (1961) e VEDAMUTHU et alii. (1964) o sabor adocicado, chamado de sabor de frutas pelos especialistas em lati cínios, que apresentou o iogurte tipo III, na prova de degustação realizada aos 30 dias de armazenamento do produto, é um defeito causado

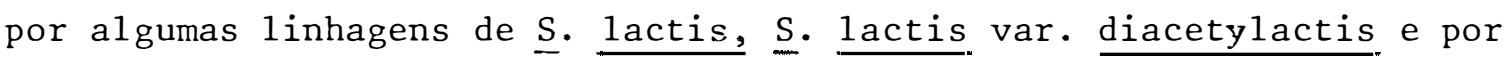
microrganismos psicrotröficos na maturação de queijos. COUSIN e MARTH (1977) citam este defeito para o iogurte. BILLS et alii. (1965) afirmam que esses microrganismos são os responsāveis por uma produção de eta nol de 6 a 16 vezes maior que nas amostras normais. Este alto nível de etanol é o responsável pela esterificação dos ācidos graxos livres produzindo assim altos níveis de etil esteres como o etil butirato e etil hexanoato, responsāveis por dito defeito no sabor, e que se encontram numa concentração de 2 a 10 vezes maior que nas amostras normais.

$$
0 \text { iogurte tipo I (L. bulgaricus }+\underline{S} \cdot \underline{\text { thermophilus) }} \vec{e}
$$

a combinação de culturas läticas comumente usada na indústria de lati- cínios para a produção do iogurte, e, foi utilizada neste experinento como controle.

A combinação de culturas do iogurté II (L. bulgari$\underline{\text { cus }}+\underline{S}$. thermophilus $+\underline{L}$ acidophilus), num estudo feito por LABROPOU 
LOS et alii (1982), ao ser comparada com outras combinações, obteve bons níveis em termos de produção de ácido, firmeza de gel e aceitabilidade por parte de um painel de avaliação sensorial. Resultados simi lares foram obtidos por SHARMA e SING (1982) quanto à produção de áci dos voláteis, acetaldeido e atividade proteolítica dessa combinação. Porém, DAVIS (1975) diz que o leite acidófilo apresenta problemas de adstringência e que estão sendo feitas pesquisas a respeito da sua in corporação no iogurte, que é um assunto ainda polêmico. Neste experimento essa combinação apresentou problemas de consistência um pouco fluida, e sabor um pouco amargo e ácido a partir dos 15 dias de produzido em diante. Porém, acredita-se que, dada a importância do $\underline{L}$ - acidophilus, mais pesquisas neste aspecto seriam de grande interesse.

0 iogurte tipo III foi produzido pela combinação de $\underline{\text { L. bulgaricus }}+\underline{\mathrm{s}}$. thermophilus $+\underline{\mathrm{s}}$. 1actis var. diacetylactis. RASIC e MILANOVIC (1966) afirmam que a adição de $\underline{\mathrm{s}}$. diacetylactis a iogurte incrementa o conteúdo de diacetil e também de acetaldeido. Portanto, es ses autores consideram que a incorporação dessa cultura melhora o sabor e aroma. Porēm, neste experimento essa combinação não foi das me 1hores qualificadas, e, além disso, no fim do período de armazenamento (30 dias) apresentou o comentado sabor de frutas.

o iogurte tipo IV foi uma combinação de L. bulgari$\underline{\text { cus }}+\underline{S}$. thermophilus $+\underline{L}$. cremoris. $0 \underline{\text { L. cremoris }}$ é o principal microrganismo fermentador do ácido cítrico e produz diacetil, acetoin, e, algumas linhagens também produzem acetaldeido (COX, 1976; LAWRENCE et 
alii, 1976 e REITER, 1973). SANDINE et alii. (1972) afirmam que, em seu trabalho, o $\underline{\text { L }}$ cremoris foi útil para melhorar o sabor do queijo Cottage. No presente trabalho esta combinação resultou em um produto final de boa qualidade, a qual foi mantida ao longo de todo o período de armazenamento. 
58.

\section{CONCLUSÕES}

Após a análise e discussão dos resultados, concluiu-se que:

1. Nas primeiras 24 horas de produzido os iogurtes, os tipos II e IV foram os que se apresentaram como os melhores qualificados em relação à textura, aroma e sabor; mas com respeito à cor e consistência o iogurte tipo IV foi o melhor qualificado.

2. Aos 15 e 30 dias de armazenamento o iogurte tipo IV foi o melhor qualificado para os 5 atributos organolépticos avaliados na anālise sensorial.

3. Quanto ao poder de pós-acidificação as combinações de culturas láticas estudadas se comportaram de maneira semelhante. 
4. Dentre as combinações de culturas láticas experimentadas a que melhores e mais estāveis atributos fornecem ao produto foi: Lactobacillus bulgaricus + Streptococcus thermophilus + Lactobacillus cremoris $(1,5 \%+1,5 \%+1 \%)$ necessitando entretanto, para o seu emprego in dustrial, estudos mars detalhados. 
ACOTT, K.M. e T.P. LABUZA, 1972. Food Prod. Dev. 6, 50: IN: DEETH, H.C. e A.Y. TAMIME, 1981. Yogurt: Nutritive and therapeutic aspects. J. Food: Protect., vol. $44(1):$ 78-86.

AUCLAIR, J.E. e A. PORTMAN, 1959. Influence du chauffage du lait sur le développement des bactéries. Le Lait, 39: 496-519.

AYEBO, A.D. e K.M. SHAHANI, 1980. Role of cultured dairy products in the diet. Cult. Dairy Prod. J., vol 15(4): 21-29.

BABEL, F.J., 1977. Antibiosis by 1actic culture bacteria. J. Dairy Sc., $\underline{60}(5): 815-821$.

BAISYA, R.K. e A.N. BOSE, 1975. Indian J. Dairy Sc., 28: 179. IN: TAMI ME, A.Y. e H.C. DEETH, 1980. J. Food Prot., 43(12): 939-977.

BALENSIFER, A., 1971. Proteina. Sua importância na alimentação. Boletim do Leite, ano XLIV, 518: 19-20. 
BARIBO, L.E. e E.M. FOSTER, 1951. The production of a growth inhibition by lactic streptococci. J. Dairy Sci., 34: 1136.

BILLS, D.D., M.E. MORGAN, L.M. LIBBEY e E.A. DAY, 1965. Identification of compounds responsible for fruity flavor defect of experimental cheddar cheeses. J. Dairy Sc., vol. 48: 1168-1173.

BLANC, B., 1973. Schweiz, Milchz. 60/61, 3. IN: DEETH, H.C. e A.Y. TAMIME, 1981. Yogurt: Nutritive and therapeutic aspects. J. Food Protect., $44(1): 78-86$.

BOLETIM DO LEITE, 1971 (Nọ 513)；1972 (Nọ 525); 1973 (Nọ 539); 1975 (NO 556).

BOTTAZZI, V. e F. DELLAGLIO, 1967. Adetaldehyde and diacety1 production by Streptococcus thermophilus and their lactic Streptococci. J. Dairy Res., 34: 109.

BOTTAZZI, V. e M. VESCOVO, 1969. Carbonyl compounds produced by yoghurt bacteria. Neth. Milk Dairy J., 23: 71-78.

BRESLAW, E.S. e D.H. KLEYN, 1973. In vitro digestibility of protein in yogurt at various stages of processing. J. Food Sci., 38: 1016.

BRYAN, A.H., 1965. Lactobacilli for enteric infections. Drug. Cosmet. Ind., 96: 474 .

CERNA, J., J. PICKOVA e J. BLATTNA, 1973. Effect of dairy cultures on vitamins contents in milk. Dairy Sci.Abstr., 35: 413.

CHAIB DE MORAES, M.A., 1983. Métodos para avaliação sensorial dos ali mentos. UNICAMP, $80 \mathrm{pP}$. 
CHUNG, K.C. e J.M. GOEPFERT, 1970. Growth of Salmonella at low pH. J. Food Sc., 35: 326 .

COCHRAN, W.G. e G.M. COX, 1957. Diseños Experimentales. Edit. Trillas, México, 661 p. 1971.

COLLINS, E.B., 1961. Dominations among strains of lactic streptococci with attention to antibiotic production. App1. Microbio1., 9: 200.

COLLINS, E.B., 1972. Biosynthesis of flavor compounds by microorganisms. J. Dairy Sc., 55(7): 1022-28.

COLLINS, E.B. e K. ARAMAKI, 1980. Production of hydrogen peroxide by Lactobacillus acidophilus. J. Dairy Sc., 63: 353-357.

COUSIN, M.A. e E.H. MARTH, 1977. Cottage cheese and yogurt manufactured from milks precultured with psychrotrophic bacteria . Cult. Dairy Prod. J., 12(2): 15-18.

CoX, W.A., 1976. Characteristics and use of starter cultures in the ma nufacture of hard pressed cheese. J. Soc. Dairy Technol., 30(1): 5-15 .

CZARNOCKA-ROCZNIAKOWA, B. e M. WOJEWODZKA, 1970. Changes in ascorbic acid content of vitaminized milk during fermentation induced by yoghurt microflora. Dairy Sci.Abstr., 32: 186.

DAHIYA, R.S. e M.L. SPECK, 1962. Symbiosis among lactic streptococci. J. Dairy Sc., 45(2): 607-612.

DAHIYA, R.S. e M.L. SPECK, 1968. Hydrogen peroxide formation by lactobacilli. and its effects on Staphylococcus aureus. J. Dairy Sc., 51 (10): $1568-1572$. 
DALY, C., W.E. SANDINE e P.R. ELLIKER, 1970. Associative growth and inhibitory properties of Streptococcus diacetilactis. J. Dairy Sc., 53(5): 637 .

DAVEY, G.P. e B.C. RICHARDSON, 1981. Purification and some properties of diplococcin from Streptococcus cremoris 346. Applied Environ. Microbiol., 41: 84-89.

DAVIES, L. e M.D. HOLDSWORTH, 1978. The place of milk in the dietary of the elderly. J. Hum. Nutr., 32: 195-200.

DAVIS, J.G., 1952a. Yogurt I. Food 21: 249.

DAVIS, J.G., 1952b. Yogurt II. Food 21: 284.

DAVIS, J.G., 1971. Standards for yogurt. Dairy Inds., 36: 456-462. IN: HAAST, J. DE, P.M. LATEgan e J.C. NOVEllo, 1979. S. Afr. J. Dairy. Technol., vol 11(1): 11-15.

DAVIS, J.G., 1975. The microbiology of yoghurt. Lactic acid bacteria in beverages and foods. Academic Press, London - New York.

DAVIS, A., 1978. Lets eat right to keep fit. pag. 86. Third Impression, Cox \& Wyman Ltd., London, UK. IN: DEETH, H.C. e A.Y. TAMIME, 1981. Yo ghurt: Nutritive and therapeutic aspects. J. Food Protect., $44(1)$ : $78-86$.

DAVIS, J.G. e D. LATTO, 1957. Lancet 272, 274. IN: DEETH, H.C. e TAMI ME, 1981. Yogurt: Nurtitive and Therapeutic aspects. J. Food Protect., $44(1): 78-86$. 
DAWSON, E.H., J.L. GROGDON e S. MCMANUS, 1963. Sensory testing of diffe rences in taste. II. Selection of panel members. Food Technol., 17 (10): $39-43$.

DAWSON, E.H. e B.L. HARRIS, 1951. Sensory methods for measuring diffe rences in food quality. U.S.D.A. Bureau of Human Nutrition and Home Economics Agriculture Information Bulletin No 34, 19-25. IN: GUIDE BOOK FOR SENSORY TESTING, 1966. Continental Can Co., Inc. Chicago, Illinois.

DEETH, H.C. e A.Y. TAMIME, 1981. Yogurt: Nutritive and Therapeutic Aspects. J. Food Protect., 44(1): 78-86.

DOAN, F.J. e J.L. DIZIKES, 1942. Digestion characteristics of various types of milk compared with human milk. Pa. Agric. Exp. Sta., 428 . IN: FERREIRA, C.L.L.F., 1978. Elementos composicionais e aspectos nutritivos do leite e iogurte. Rev. do ILCT, 33(200): 13-17.

DRIESSEN, F.M., F. KINGMA e J. STADHOUDERS, 1982. Evidence that Lactobacillus bulgaricus in yogurt is stimulated by carbon dioxide produced by Streptococcus thermophilus. Neth. Milk Dairy J., 36(2) : $135-144$.

DUPUIS, Y., 1964. Fermented milks. IDF Annual Bulletin, Part III, page 36, Bruxelles, Belgium. IN: DEETH, H.C. e A.Y. TAMIME, 1981. Yo gurt: Nutritive and therapeutic aspects. J.Food Protect., $44(1)$ : $78-86$.

DURBIN, J., 1951. Incomplete blocks in ranking experiments. The British J. of Psychology (Statistical Section), 4: 85-90. IN: SHIROSE, I. Bo1. ITAL, 19(2): 113-132. 
65.

DUTTA, S.M., R.K. KUILA, B. RANGANATHAN e H. LAXMINARAYANA, 1971. Indian J. Dairy Sc., 24: 107. IN: TAMIME, A.Y. e H.C. DEETH, 1980. J. Food Prot., 43(12): 937-977.

DUTTA, S.M., R.K. KUILA e B. RANGANATHAN, 1973. Milchwissenschaft 28: 231. IN: TAMIME, A.Y. e H.C. DEETH, 1980. J. Food Prot. 43(12):939-977. ERDMAN, M.D., W.G. BERGEN e C.A. REDDY, 1977. Amino acid profiles and presumptive nutritional assessment of single-cell protein from certain lactobacilli. Appl. Environ. Microbiol., 33(4): 901-905.

FERREIRA, C.L.L.F., 1978. Elementos composicionais e aspectos nutritivos do leite e iogurte. Rev. do ILCT, 33(200): 13-17.

FERREIRA, C.L.L.F., 1979. Valor terapêutico do iogurte e leite acidofi 1o. Rev. Inst. Laticínios Cândido Tostes, 34(202): 25-27.

FERRER, F.P. e L.J. BOYD, 1955. Amer. J. Dig. Dis. 22, 272. IN: DEETH, H.C. e A.Y. TAMIME, 1981. Yogurt: Nutritive and therapeutic aspects. J. Food Protect., 44(1): 78-86.

GALESLOOT, T.E. e F. HASSING, 1966. Heating of yoghurt milk in an in-flow sterilizer. Dairy Sci. Abstr., 28: 184.

GALESLOOT, T.E. e F. HASSING, 1973. Maintaining the mucus production of yogurt cultures. Mededeling, Nederlands Instituut voor Zuivelonderzoek 7: 57-62. IN: HAAST, J. DE, P.M. LATEGAN e J.C. NOVELlO. S. Afr. J. Dairy Technol., 1979, 11(1): 11-15.

GALESLOOT, T.E., F. HASSING e H.A. VERINGA, 1968. Neth. Milk Dairy J., 22: 50-63.' IN: DRIESSEN, F.M., F. KINGMA e J. STADHOUDERS. 1982. Neth. Milk Dairy J., 36 (2): 135-144.

GILLILAND, S.E. e M.L. SPECK, 1977. Antagonistic action of Lactobacillus. acidophilus toward intestinal and foodborne pathogens in associative cultures. J. Food Protect., 40: 820-823. 
GOODENOUGH, E.R. e D.H. KLEYN, 1975. Qualitative and quantitative chan ges in carbohydrates during the manufacture of yogurt. J. Dairy Sc. 59: $45-47$.

GOODENOUGH, E.R. e D.H. KLEYN, 1976. Influence of viable yogurt microflora on digestion of lactose by the rat. J. Dairy Sc., 59(4): 601-606 .

GREEN, M.L., 1980. The formation and structure of milk protein gels . Food Chemistry, 6: 41-49.

GROSSOWICS, N., D. KAPLAN e S. SCHLEERSON, 1947. Production of an antibiotic substance by a lactobacillus. Rep. Proc. Int. Congr. Microbiol., Copenhagen, $4^{\text {th }}, 137$.

GROUX, M., 1973. Critical observations of yogurt manufacture with refe rence to protein break down. Dairy Sc. Abstr., 35: 1474.

GROUX, M. 1976. "Nestle"" Research News 1974/75, pag. 50. Ed. Boella, C: Nestlé Products Technical Assistance Co. Ltd. 1001, Lausanne, Switzer land. IN: TAMIME, A.Y. e H.C. DEETH, 1980. J. Food Prot., 43(12) : 937-977.

GUIDONI, A.L., 1978. Extensão do teste de "Friedman" aos blocos incompletos equilibrados. Seminārio apresentado ao Curso de Pós-Graduação em Experimentação e Estatística, ESALQ/USP, 13 p. IN: SHIROSE, I., Bol. ITAL, 19(2): 113-132.

HAAST, J. DE, P.M. LATEGAN e J.C. NOVELLO, 1979. Some aspects of yogurt quality - A review. S. Afr. J. Dairy Technol., 11(1): 11-15. 
HALDEN, W., 1964. Fermented milks. IDF Annual Bulletin, Part III, page 17-21, Bruxelles, Belgium, IN: DEETH, H.C. e A.Y. TAMIME, 1981. Yogurt: Nutritive and therapeutic aspects. J. Food Protect., 44(1): 78-86.

HAMADA, K., Y. WAKI, T. KITAGAWA, K. UCHIDA, H. CHIBA et alii, 1971. Stu dies on the effect of fermented milk by Lactobacilli on human health. The Summary of Reports on Yakult. Yakult Honsha, Co., Ltd. Tokyo, Ja pan, pag. 54-56. IN: AYEBO, A.D. e K.M. SHAHANI, 1980. Role of cultured dairy products in the diet. Cult. Dairy Prod. J., 15(4): 21-29.

HAMDAM, I.Y., J.E. KUNSMAN e D.D. DEANE, 1971. Acetaldehyde production of combined yogurt cultures. J. Dairy Sc., 54: 1080.

HAMDAM, I.Y. e E.M. MIKOLAJCIK, 1973. Growth, viability and antimicrobial activity of Lactobacillus acidophilus. J. Dairy Sc., 56: 638 (Abstr.).

HARGROVE, R.E. e J.A. ALFORD, 1978. Growth rate and feed efficiency of rats fed yogurt and other fermented milks. J. Dairy Sci., 61(1): 11-19 .

HARGROVE, R.E. e J.A. ALFORD, 1980. Growth response of weanling rats to heated, aged, fractionated and chemically treated yogurts. J. Dairy Sci., 63: 1065-1072.

HARVEY, R.J., 1960. Production of acetaldehyde and acetone by lactic streptococci. J. Dairy Res. 27: 41.

HARVEY, R.J. e E.B. COLLINS, 1961. Role of citritase in acetoin formation by Streptococcus diacetilactis and Leuconostoc citrovorum. J. Bacterio1, 82: 954 . 
HEMPENIUS, W.L. e B.J.LISKA, 1964. Preliminary observations on production of natural flavor in chemically acidified cream and skim milk. J. Dairy Sc. 47: 1099-1101.

HUMPHREYS, C.L. e M. PLUNKETT, 1969. Yogurt: A review of its manufac ture. Dairy Sci. Abstr., 31: 607-622.

IANDOLA, J.J., C.W. CLARK, L. BLUHM e Z.J. ORDAL, 1965. Repression of Staphylococcus aureus in associative culture. Appl. Microbiol., 13: 646.

JUFFS, H.S. e F.J. BABEL, 1975. Inhibition of psychrotrophic bacteria by lactic cultures in milk stored at low temperatures. J. Dairy Sc., 58(11): 1612 .

KARLIN, R., 1961. Ann. Nutr. Aliment. 15, 247. IN: DEETH, H.C. e A.Y. TAMIME, 1981. Yogurt: Nutritive and therapeutic aspects. J. Food Protect., $44(1): 78-86$.

KEENAN, T.W. e D.D. BILLS, 1968. Metabolism of volatile compounds by lactic starter culture microorganisms. A review. J. Dairy Se., 51: 1561-1567.

KELLY, L.L., 1984. Lactose intolerance - Could yogurt be the answer? Cult. Dairy Prod. J., 19(2): 12-14.

KETZ, H.A., 1972. Zur Ernährung im Altar. Ernahrungs forschung, 17:351389. IN: RENNER, E., 1982. Aspectos nutritivos fisiológicos da proteina do leite. Boletim do Leite, ano LIV, № 643: 34-42.

KILARA, A. e K.M. SHAHANI, 1976. Lactose activity of cultured and acidified dairy products. J. Dairy Sci., 59: 2031-2035.

KILARA, A. e K.M. SHAHANI, 1978. Lactic fermentations of dairy foods and their biological significance. J. Dairy Sc., 61(12): 1793-1800. 
KODAMA, R., 1952. Studies on lactic acid bacteria. II. Lactolin, a new antibiotic substance produced by lactic acid bacteria. J. Antibiotics, $\underline{5}: 72$.

KOLARS, J.C., M.D. LEVITT, M. AOUJI e D.A. SAVAIANO, 1984. Yogurt an autodigesting source of lactose. New England J. of Medicine, 310: 1-3.

KOSIKOWSKI, F., 1970. Cheese and fermented milk foods. Edward Brothers Inc. Michigan, $429 \mathrm{pp}$.

KROGER, M., 1976. Quality of yogurt. J. Dairy Sc., 59(2): 344-350.

KROGER, M., 1978. Arguments for yogurt with viable bacteria. Cult. Dairy Prod. J., 45(2): 607-612.

KURMANN, J.A., 1977. Os fatores biológicos e técnicos da fabricação do iogurte. Anais do IV Congresso Nacional de Laticínios, 74-84.

LABROPOULOS, A.E., W.F. COLLINS e W.K. §TONE, 1982. Starter culture effects on yogurt fermentation. Cult. Dairy Prod. J., 17(2): 15-17.

LAWRENCE, R.C., T.D. THOMAS e B.E. TERZAGHI, 1976. Reviews of the progress of dairy science: cheese starters. J. Dairy Res., 43(1): 141-193 .

LEES, G.J. e G.R. JAGO, 1976a. Acetaldehyde: An intermediate in the for mation of ethanol from glucose by lactic acid bacteria. J. Dairy Res. 43: $63-73$.

LESS, G.J. e G.R. JAGO, 1976b. Formation of acetaldehyde production from threonine by lactic acid bacteria. J. Dairy Res., 43: 75-83. 
LUCK, H. e J.F. MOSTERT, 1971. Pasteurization of fermented milk products. S.Afr. J. Dairy Techno1. 3(2): 75-80.

LUCZYNKA, A., F. BIJOK, T. WAJNERT, W. KAZIMIERCZAK, E. LIPINSKA, M. KO SIKOWSKA e E. JAKUBCZYK, 1978. XX International Dairy Congress E, 836. IN: TAMIME, A.Y. e H.C. DEETH, 1980. J. Food Prot., 43(2): 939-977.

LUNDSTEDT, E. e W.B. FOGG, 1962. Inducing flavor in Cottage Cheese through citratied whey starters. Milk Dealer, 51(1): 46.

MANN, G.V. e A. SPOERRY, 1974. Studies of a surfactant and cholesteremia in the Maasai. Amer. J. C1in. Nutr. 27: 464. IN: M.L. SPECK, 1976. Interactions among lactobacilli and man. J. Dairy Sci., 59(2): 338343 .

MANSON, W., 1975. Nutritional aspects of milk protein. J. Soc. Dairy. Techno1., 28: 203-208.

MARSHALL, C.E., 1905. Extended studies of the associative action of bac teria in the souring of milk. Spec. Bul1., Mich. Agr. Expt. Sta., No 33. IN: DAHIYA, R.S. e M.L. SPECK, 1962. Symbiosis among Lactic streptococci. J. Dairy Sci., 45(2): 607-612.

MARSHALL, C.E. e B. FERRAND, 1908. Bacterial association in the souring of milk. Spec. Bull., Mich. Agr. Exp. Sta., No 42. IN: DAHIYA, R.S. e M.L. SPECK, 1962. Symbiosis among lactic streptococci. J. Dairy. $\underline{\text { Sci.. }}$ 45(2): 607-612.

MARTH, E.H. e R.V. HUSSONG, 1963. Effect of skimmilks cultured with different strains of Leuconostoc citrovorum on growth of some bacte ria and yeasts. J. Dairy Sci., 46: 1033-1037. 
MARTINELLI FILHO, A., (s.d.). Microbiologia de alimentos I. Piracicaba, ESALQ/USP, 160-164.

MATHER, D.W. e F.J. BABEL, 1959. Inhibition of certain types of bacte rial spoilage in creamed Cottage cheese by the use of creaming mixtu re prepared with Streptococcus citrovorus. J. Dairy Sci., 42: 1917-1926 .

MAYNON-WHITE, R.M. e M.C. IRVING, 1951. Cyanosis in infancy from nitra tes indrinking water. Lancet, 260: 931. IN: FERREIRA, C.L.L.F., 1979 . Valor terapêutico do iogurte e leite acidófilo. Rev. Inst. Latic. Candido Tostes, 34(202): 25-27.

MEL'NIKOVA, E.V. e N.S. KOROLEVA, 1975. Capacity of a L. bulgaricum and

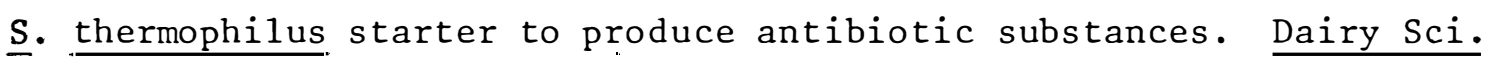
Abstr., 37: 413 .

MILLER, I. e O. KANDLER, 1964. Med. u. Ernahr, 5: 100-108. IN: DRIES SEN, F.M., F. KINGMA e J.S. STADHOUDERS, 1982. Evidence that Lactobacillus bulgaricus in yogurt is stimulated by carbon dioxide produced by Streptococcus thermophilus. Neth. Milk Dairy J., 36(2) : 135-144.

MITIC, S., I. OTENHAJMER e D. OBRADOVIC, 1974. A study of bacterial an tagonisms of strains of Lactobacillus acidophilus towards some test organisms. Dairy Sci. Abstr., 36: 656.

MITSUOKA, T., 1972. Conversion and manufacture of foodstuffs by microor ganisms. Saikon Pub. Co., Japan: 169-180. 
MORI, E.E.M., I. SHIROSE, V.L.P. FERREIRA e S.D.S. de CAMPOS, 1983. Mé todos sensoriais e físicos para avaliação de alimentos e bebidas: Princípios e Aplicação. ITAL, Campinas.

MUTAI, M., K. ASO e M. SHIROTA, 1972. Conversion and manufacture of foodstuffs by microorganisms. Saikon Publishing Co.: 181-189, Japan.

NAKAE, T. e J.A. ELLIOTT, 1965. Volatile Eatty acids produced by some lactic acid bacteria. I. Factors influencing production of volatile fatty acids from casein hydrolysate. J. Dairy Sc., 48: 287-292.

NIELSEN, V.H., 1976. Factors wich control the body and texture of commercial yogurts. American Dairy Review, (36): 36-38.

NIV, M., W. LEVY e N.M. GREENSTEIN, 1963. Clin. Pediat. 2, 407. IN: DEETH, H.C. e A.Y. TAMIME, 1981. Yogurt: Nutritive and therapeutic aspects. J. Food Protect., 44(1): 78-86.

NURMIKKO, V., 1953. Factors affecting the growth of lactic acid bacteria in association. Intern. Dairy Congr., The Hague, 3: 1154.

ODUM, E.P., 1971. Fundamentals of ecology. p. 211-212. Philadelphia, London, Toronto, W.B. Saunders.

OLIVEIRA, J.S., 1969/70. Inibição de Pseudomonas putrefaciens for Streptococcus diacetilactis e Leuconostoc citrovorum. Coletânea do ITAL. vol. 3: 115-128.

O'NEIL, J.M., D.H. KLEYN e L.B. KARE, 1979. Consistency and compositio nal characteristics of commercial yogurts. J. Dairy Sci., 62(6): 1032-1036. 
PEARCE, L.E. e H.A. HEAP; 1974. Town Milk J. of the New Zealand Milk Board 22, 18. IN: ROBINSON, R.K. e A.Y. TAMIME, 1975. Yogurt a re view of the product and its manufacture. J. Soc. Dairy Techno1., 28 (3) : $149-163$.

PERRY, K.D., 1961. A comparison of the influence of Streptococcus lac$\underline{\text { tis }}$ and S. cremoris starters on the flavour of Cheddar cheese. J. Dairy Res., 28(3): 221-230.

PETTE, J.W. e H. LOLKEMA, 1950. Yogurt. III. Acid production and aroma formation in yogurt. Netherlands Milk Dairy J., 4: 261.

PINHEIRO, A.J.R., B.J. LISKA e C.E. PARMELEE, 1968. Properties of subs tances inhibitory to Pseudomonas fragi produced by Streptococcus citrovorus e Streptococcus diacetilactis. J. Dairy Sc., 51(2): 183-187 .

PONCE, I.F. e E.L. PIÑEYRO, 1974. Elaboração de queijos e leites fermen tados. Univ. Est. de Campinas, 146 pp., Brasil.

PRICE, R.J. e J.S. LEE, 1970. 'Inhibition of Pseudomonas species by hy drogen peroxide producing lactobacilli. J. Milk Food Technol., 33: 13.

PULUSANI, S.R., D.R. RAO e G.R. SUNKI, 1979. Antimicrobial activity of lactic cultures: partial purification and characterization of antimi crobial compund produced by Streptococcus thermophilus. J.Food Sc. 44:575.

RASIC, J. e J.A. KURMAN, 1978. Yogurt: scientific grounds, technology, manufacture and preparations. vo1. 1, 110 pag. Dairy Publ. House. Copenhagen. Denmark.

RASIC, J. e Z. MILANOVIC, 1966. XVII Int. Dairy Congr. E/F 637. IN: HUMPHREYS, C.L. e M. PLUNKETT, 1969. Dairy Sci. Abstr., 31(11): 607622 . 
RASIC, J., T. STOJSAVLJEVIC e R. CURIC, 1971. A study of the amino acids of yogurt. II. Amino acids content and biological value of protein of different kinds of yogurt. Milchwissenschaft, 26: 219-224.

REDDY, G.V. e K.M. SHAHANI, 1971. Isolation of an antibiotic from Lactobacillus bulgaricus. J. Dairy Sc., 54: 748 (Abstr.)

REDDY, G.V., K.M. SHAHANI e M.R. BANERJEE, 1973. Inhibitory effect of yogurt on Erlich Ascites tumor cell proliferation. J. Natl. Cancer, Inst., 50: 815-817. IN: Cult. Dairy Prod. J., 8 8(3): 7.

REDDY, G.V., K.M. SHAHANI, B.A. FRIEND e R.C. CHANDAN, 1984. Natura1 antibiotic activity of Lactobacillus acidophilus and bulgaricus. III. Production and partial purification of bulgarican from Lactobacillus. bulgaricus. Cu1t. Dairy Prod. J., 19(2): 7-11.

REDDY, K.P., K.M. SHAHANI e S.M. KULKARNI, 1976. B-Complex vitamins in Cultured and acidified yogurt. J. Dairy Sci., 59(2): 191-195.

REITER, B., 1973. Some thoughts on cheese starters. J. Soc. Dairy Techno1., 26(1): 3-21.

RENNER, E., 1982. Aspectos nutritivos fisiológicos da proteina do leite. Boletim do Leite, ano LIV, Nọ 643: 34-42.

RENZ, U. e Z. PUHAN, 1975. Milchuvissenschaft, 30: 265.

ROCHIETTA, V., 1975. Intestinal microflora of infants fed $\underline{\text { }}$. bulgaricus. e . thermophilus. Dairy Sci. Abstr., 37: 778 . 
RUBIN, H.E., T. NERAD e F. VAUGHAN, 1982. Lactic acid inhibition of Salmonella typhimurium in yogurt. J. Dairy Sci., 65: 197-203.

SALJI, J.P. e A.A. ISMAIL, 1983. Effect of initial acidity of plain yogurt on acidity changes during refrigerated storage. J. Food Sci., 48(1): 258-259.

SALVADORI, P. e B.B. SALVADORI, 1974. Variations in the microflora of human faeces with feeding of yoghurt. Dairy Sci. Abstr., 36: 44.

SANDINE, W.E., 1979. Roles of Lactobacillus in the intestinal tract. J. Food Prot., 42(3): 259-262.

SANDINE, W.E., C. DALY, P.R. ELLIKER e E.R. VEDAMUTHU, 1972. Causes and control of culture - related flavor defects in cultured dairy products. J. Dairy Sci., 55(7): 1031-1039.

SANDINE, W.E. e P.R. ELLIKER, Microbially induced flavours and fermented foods. Flavour in fermented dairy products. (A review). J. Agric. Fd. Chem., 18: 557-562.

SELLARS, R.L. e F.J. BABEL, 1970. Cultures for the manufacture of dai ry products. Chr. Hansen's Lab. Inc., Wisconsin, pp. 46-49.

SHAHANI, K.M. e A.D. AYEBO, 1980. Role of dietary lactobacilli in gastrointestinal microecology. Am. J. Clin.Nutr.33 (In Press) IN: A.D. AYEBO e K.M. SHAHANI, 1980. Role of cultured dairy products in the diet. Cult. Dairy Prod. J., 15(4): 21-29.

SHAHANI, K.M. e R.C. CHANDAN, 1979. Nutritional and healthful aspects of cultured and culture - containing dairy foods. J. Dairy Sci., 62 : 1685-1694. 
SHAHANI, K.M., G.V. REDDY e A.M. JOE, 1974. XIX Int. Dairy Cong. IE, 569. IN: DEETH, H.C. e A.Y. TAMIME, 1981. Yogurt: Nutritive and therapeutic aspects. J. Food Protect., 44(1): 78-86.

SHAHANI, K.M., J.R. VAKIL e A. KILARA, 1976. Natural antibiotic activi ty of Lactobacillus acidophilus and bulgaricus. I. Cultural conditions for the production of antibiosis. Cult. Dairy Prod. J., 11 (4): 14-17.

SHAHANI, K.M., J.R. VAKIL e A. KILARA, 1977. Natural antibiotic activi ty of Lactobacillus acidophilus and bulgaricus. II. Isolation of acidophilin from L. acidophilus. Cult. Dairy Prod. J., 12 (2) : 8-11.

SHANKAR, P.A. e F.L. DAVIES, 1977. Amino acid and peptide utilization by Streptococcus thermophilus in relation to yogurt manufacture. J. App1. Bact., 43, VIII.

SHANKAR, P.A. e H. LAXMINARAYANA, 1974. XIX Inter. Dairy Congr. IE, 744. IN: DEETH, H.C. e A.Y. TAMIME, 1981. Yogurt: Nutritive and therapeutic aspects. J. Food Protect., 44(1): 78-86.

SHARMA, N. e D.N. GANDHI, 1981. Preparation of acidophilin. I. Selection of the starter culture. Cult. Dairy Prod. J., 16(2): 6-10.

SHARMA, D.K. e J. SING, 1982. Yogurt starters in skim milk. II. Beha vior of Lactobacillus acidophilus in yogurt starters. Cult. Dairy. Prod. J., 17(4): 10-12.

SHARPE, M.E., 1979. Lactic acid bacteria in the dairy industry. J. Soc. Dairy Tech., 32(1): 9-18. 
SHARPE, M.E., E.I. GARVIE e R.H. TILBURY, 1972. Some slime-forming he terofermentative species of the genus Lactobacillus. Appl. Microbiol. 23: 389-397.

SHIROSE, I., 1982. Anālise de variância não-paramétrica dos delineamen tos em blocos incompletos balanceados. Bol. ITAL, 19(2): 113-132.

SIMHAEE, E. e E. KESHAVARZ, 1974. Comparison of gross protein value and metabolizable energy of dried skim milk and dried yogurt. Poultry. Sci., 53: 184 .

SINGH, J., A. KHANNA e H. CHANDER, 1979. Antibacterial activity of yogurt starter in cow and buffalo milk. J. Food Protect., 42(8): 664-665 .

SORRELLS, K.M. e M.L. SPECK, 1970. Inhibition of Salmonella gallinarum. by culture filtrates of Leuconostoc citrovorum. J. Dairy Sc., 53: 239.

SPECK, M.L., 1972. Control of food-borne pathogens by starter cultures. J. Dairy Sc., 55(7): 1019-1022.

SPECK, M.L., 1976. Interactions among lactobacilli and man. J. Dairy Sc., $59(2): 338-343$.

SPECK, M.L., 1977. Heated yogurt - is it still yogurt ? J. Food Prot. 40: 863-865.

SPECK, M.L., 1983. Evidence of value of live starter culture in yogurt. Cult. Dairy Prod. J., 18(1): 25-26. 
TAMIME, A.Y., 1977. Some aspects of the production of yogurt and con densed yogurt. Ph.D. Thesis, University of Reading, Berkshire, UK.

TAMIME, A.Y., 1978a.. XX International Dairy Congress E, 832. IN: TAMI ME, A.Y. e H.C. DEETH, 1980. J. Food Prot., 43(12): 939-977.

TAMIME, A.Y., 1978b. Cultured Dairy Prod. J., 13: 16. IN: TAMIME, A. Y. e H.C. DEETH, 1980. J. Food Prot., 43(12): 939-977.

TAMIME, A.Y. e H.C. DEETH, 1980. Yogurt: Technology and Biochemistry. J. Food Prot., 43(12): 939-977.

TAMIME, A.Y. e R.K. ROBINSON, 1978. Milchwissenschaft, 33: 209. IN: TA MIME, A.Y. e H.C. DEETH, 1980. J.Food Prot., 43(12): 939-977.

TODOROV, D., 1962. The bacteriological properties of yogurt organisms. Dairy Sci. Abstr., 24: 309.

VAKIL, J.R. e K.M. SHAHANI, 1965. Partial purification of antibacterial activity of Lactobacillus acidophilus. Bacterial. Proc., p. 9.

VEDAMUTHU, E.R., W.E. SANDINE e P.R. ELLIKER, 1964. Influence of strain composition of lactic starter on flavor and texture of Cheddar cheese. J. Dairy Sci., 47: 679 .

VERINGA, H.A., 1973. Biochemistry of yogurt. Mededelingen, Nederlands Instituut voon Zuivelonderzoeck, No 7: 88-96. IN: HAAST, J. DE, P.M. LATEGAN e J.C. NOVELLO. S. Afr. J. Dairy Technol. 1979, 11 (1): 11-15 . 
VERINGA, H.A., T.E. GALESLOOT e H. DAVELAAR, 1968. Neth. Milk. Dairy J. 22: 114-120. IN: DRIESSEN, F.M., F. KINGMA e S. STADHOUDERS. Neth. Milk Dairy J., 36(2): 135-144.

VIANI, R. e I. HORMAN, 1976. "Nestlé" Research News 1974/75, pag. 53. Ed. Boella, C. Nestlé Products Technical Assistance Co. Ltd. 1001 , Lousanne, Switzerland. IN: TAMIME, A.Y. e H.C. DEETH, 1980. J. Food Prot., 43(12): 937-977.

WEINER, N. e P. DRASKOCZY, 1961. The effects of organic acids on the oxidative metabolism of intact and disrupted E. coli. J. Pharmacol. Exp. Ther., 132: 299.

WOLFSCHOON-POMBO, A.F., G.G.M. GRANZINOLLI e R.M. FERNANDES, 1983. Sólidos totais do leite, acidez, $\mathrm{pH}$ e viscosidade do iogurte. Rev. Inst. Latic. Cândido Tostes, 38(227): 19-24.

YAZICIOGLU, A. e N. YILMAZ, 1966. Studies on the microflora of yogurt and its action. Milshwissenchaft, 21: 87. IN: FERREIRA, C.L.L.F., 1979. Valor terapêutico do iogurte e leite acidofilo. Rev. do Inst. Latic. Cândido Tostes, 34(202): 25-27. 